\title{
Käännöstiede ja sen menetelmät
}

\section{Tiittula, Liisa}

Suomalaisen Kirjallisuuden Seura

2020

Tiittula , L \& Kolehmainen , L 2020 , Käännöstiede ja sen menetelmät . julkaisussa M Luodonpää-Manni , M Hamunen , R Konstenius, M Miestamo , U Nikanne \& K Sinnemäki (toim), Kielentutkimuksen menetelmiä I-IV . Suomalaisen Kirjallisuuden Seuran toimituksia , Nro 1457 , Suomalaisen Kirjallisuuden Seura, Helsinki, Sivut 942-983.

http://hdl.handle.net/10138/323274

cc_by_nc_nd

publishedVersion

Downloaded from Helda, University of Helsinki institutional repository.

This is an electronic reprint of the original article.

This reprint may differ from the original in pagination and typographic detail.

Please cite the original version. 


\title{
Luku 23 Käännöstiede ja sen menetelmät
}

\author{
Liisa Tiittula \\ (1) https://orcid.org/0000-0002-4688-0854 \\ Leena Kolehmainen \\ (1) https://orcid.org/0000-0003-2746-7201
}

\section{Mikä?}

Käännöstiede on termi, joka kattaa sekä kääntämisen että tulkkauksen tutkimuksen. Tutkimuksessa, jota tehdään sekä historiallisesta että nykyaikaan keskittyvästä näkökulmasta, käytetään erilaisia aineistoja ja menetelmiä tutkittaessa esimerkiksi seuraavia alueita:

- kääntämisen ja tulkkauksen tuotteita (käännöksiä ja tulkkeita),

- käännös- ja tulkkausprosessia,

- käännösten ja tulkkeiden vastaanottoa ja käyttöä (lukijoita, kuulijoita jne.),

- kääntäjiä, tulkkeja, kielentarkastajia, toimeksiantajia, kustantajia jne. (toimijoita),

- kääntämisen ja tulkkauksen toiminta- ja esiintymisympäristöjä,

- kääntäjien ja tulkkien tiedonhankintaa ja apuvälineitä sekä

- kääntäjien ja tulkkien koulutusta. 


\section{Katso myös:}

Luku 5 Lingvistinen etnografia toimintayhteisöissä

Luku 8 Käsiteanalyysi kielentutkimuksessa

Luku 9 Korpusaineistot

Luku 10 Määrällinen korpuslingvistiikka

\section{Johdanto}

Roman Jakobson (2000 [I959]) jakoi kääntämisen kieltenväliseen, kielensisäiseen ja intersemioottiseen kääntämiseen. Näistä ensiksi mainittu ja sen tutkimus muodostavat käännöstieteellisen tutkimuksen perinteisen ytimen. Yhä useammat tutkijat tarkastelevat kuitenkin myös kielensisäistä (mukaelmat, siirtymä kirjoitetusta moodista suulliseen ja päinvastoin) ja intersemioottista (siirtymä merkkijärjestelmästä toiseen) kääntämistä, sillä monet käännösviestinnän osa-alueet sisältävät komponentteja useammasta Jakobsonin erottamasta luokasta (esim. kirjoitustulkkaus, kuvailutulkkaus ja ohjelmatekstitys).

Kääntäminen ja sen tutkimus on ollut tapana jakaa osa-alueisiin tekstilajeittain kirjallisuuden kääntämiseen (kauno- ja tietokirjallisuus), asiatekstien kääntämiseen (lait, sopimukset, todistukset, esitteet jne.) ja av-kääntämiseen (audiovisuaalinen kääntäminen: tv-ohjelmien, elokuvien, oopperan jne. tekstitys, selostusteksti, ohjelmatekstitys, dubbaus, verkkosivujen ja pelien kääntäminen). Tulkkausta ja sen tutkimusta taas voidaan lähestyä tulkkausmenetelmästä (simultaani-, konsekutiivi-, kuiskaustulkkaus) tai tulkkaustilanteesta käsin (oikeus-, asioimis-, konferenssi-, neuvottelutulkkaus), teknologiset mahdollisuudet huomioiden (lähi- ja etätulkkaus), kielimuodon näkökulmasta (puhuttujen kielten vs. viittomakielen tulkkaus) tai erityiskohderyhmä ja aistirajoite huomioiden (kuvailutulkkaus, kirjoitustulkkaus, 
puhevammaistulkkaus, taktiilitulkkaus). Mahdollisesti tuorein jaottelu koskee toimijoita: maallikko-, fani-, vapaaehtois- ja joukkoistetun kääntämisen ja tulkkauksen tutkimus on ammattikääntäjien ja -tulkkien toiminnan tutkimuksen rinnalle kehittynyt uusi tutkimussuuntaus. Käännöstieteen alaan luetaan usein myös lähikäsitteet tekninen viestintä ja lokalisointi: Ensimmäisellä tarkoitetaan työtehtäviä, joissa henkilö vastaa erilaisten teknisten tekstien ja dokumenttien, kuten käyttöohjeiden tai huolto- ja asennusoppaiden, kirjoittamisesta ja päivittämisestä. Jälkimmäinen taas viittaa tuotteiden, kuten tietokoneohjelmien ja -pelien, sovittamiseen eri kieli- ja kulttuuriympäristöjen käyttäjille sopiviksi.

Joskus käännöstieteen rinnalle nostetaan omana suuntauksenaan tulkkaukseen keskittyvä tulkkaustiede. Tässä artikkelissa käytämme yläkäsitteenä käännöstiedettä ja tarkastelemme sekä kääntämistä että tulkkausta. Koska käännöstiede on tutkimuskohteiltaan monialainen, tutkijat käyttävät samoja menetelmiä kuin lähitieteenaloilla käytetään, erityisesti kielitieteessä (esim. korpustutkimus, vertaileva tekstintutkimus), kirjallisuustieteessä ja yhteiskuntatieteissä (esim. kysely, haastattelu, havainnointi). Yhtymäkohtia on lukuisiin muihinkin tieteenaloihin, esimerkiksi kulttuurintutkimukseen, historiantutkimukseen, tietojenkäsittelytieteeseen ja kognitiotieteeseen.

Seuraavassa luodaan katsaus käännöstieteelliseen tutkimukseen, siihen, millaisin aineistoin ja analyysimenetelmin ja mihin tarkoituksiin kieltä, tekstejä ja vuorovaikutusta analysoidaan käännöstieteessä. Havainnollistamme tutkijoiden hyödyntämiä aineistoja ja aineistonkeruumenetelmiä sekä analyyseissa käyttämiä metodeja. Käännöstieteelliset tutkimukset ovat yhä useammin monimetodisia ja moniaineistoisia: tutkijat lähestyvät tutkimuskysymystään eri näkökulmista ja valottavat sitä eri aineistoin ja metodein, ja monimenetelmäisellä otteella voidaan vastata uudenlaisiin tutkimuskysymyksiin.

Keskitymme kieleen, kirjoitettuihin ja puhuttuihin teksteihin, niiden tuottamisen ja vastaanottamisen prosesseihin sekä niiden käännöstieteelliseen analyysiin ja toimijoihin. Tästä syystä esimerkiksi kääntäjien tiedonhankintaa ja apuvälineitä sekä koulutusta koskeva käännöstieteellinen tutkimus rajautuu artikkelin ulkopuolelle. Lähitutkimussuuntauksista tarkastelematta jäävät terminologinen 
(ks. Käsiteanalyysi kielentutkimuksessa tässä kirjassa) ja viittomakielen tulkkauksen tutkimus, joista molemmat ansaitsisivat kokonaan omat artikkelinsa. Myös konekääntäminen ja käännösteknologia omana tutkimuskohteenaan jää pois.

Luomme ensin lyhyen katsauksen käännöstieteen historiaan (luku 2). Sitä seuraa kuvaus käännöstieteen tutkimuskohteista, metodeista ja aineistoista (luku 3): esittelemme ensin historiallisesti perinteikkäimmän tutkimuskohteen eli käännettyjen tekstien ja tulkkeiden tutkimuksen (luvut 3.I. ja 3.2.), jonka jälkeen siirrymme kääntämisen ja tulkkauksen prosessien (3.3.) ja siihen läheisesti liittyvään toimijoiden, toimintaympäristön ja vastaanoton tutkimukseen (3.4.). Viimeinen luku 4 kokoaa keskeisiä tendenssejä yhteen.

\section{Käännöstieteen historiaa ja taustaa}

\section{Kielikäsitys}

Käännöstieteessä käsitys kielestä vaihtelee niin tutkimussuunnittain kuin historiallisesti. Kieli nähdään usein välineenä: yhteinen kieli mahdollistaa vuorovaikutuksen eri osapuolten välille, yhteisen kielen puuttuminen taas muodostaa esteen viestinnälle. Kääntäjät ja tulkit luovat sillan osapuolten välille, kun erilaiset kieliresurssit ovat vuorovaikutuksen esteenä tai kun aistivamma tai muut toimintarajoitteet vaikeuttavat viestinnän saavutettavuutta. He mahdollistavat kielellisten oikeuksien toteutumisen tilanteissa, joissa oman kielen käyttö taataan esimerkiksi erikielisten viranomaisten kanssa asioitaessa.

Käännöstieteessä kielikäsitykseen kuuluu käsitys kielten välisistä suhteista eli toisenkielisen käännöksen tai tulkkeen tuottamisen ehdoista, siitä, miten yhden kielen viestin pohjalta tuotetaan toisella kielellä uusi viesti uudelle vastaanottajalle ja uuteen tarkoitukseen. Käännöstieteen historiassa, erityisesti konekääntämisen alkuaikoina, kieltenvälisiä suhteita pidettiin varsin suoraviivaisina vastaavuuksina ja kääntäminen näyttäytyi 
mekaanisena toimintana. Nykyään painottuu näkemys kieltenvälisten suhteiden kompleksisuudesta. Kieltä tarkastellaankin usein suhteessa kulttuuriin, puhujayhteisöihin, erilaisiin yleisöihin ja vastaanottajaprofileihin, ideologisiin kysymyksiin, kuten valtaan, sekä vuorovaikutuksen esiintymiskontekstiin: Uuden erikielisen viestin funktio ja kontekstin tai toimintaympäristön sanelemat reunaehdot muodostavat keskeisiä kääntämiseen ja tulkkaukseen vaikuttavia asioita. Lisäksi kieli toimii osana multimodaalista kokonaisuutta. Kieli on käännöstieteessä keskeinen tiedon vaihtoon ja liikkumiseen liittyvä väline (engl. knowledge transfer). Se on myös esteettinen ilmiö, joka mahdollistaa taide-elämyksen.

Kirjallisen kääntämisen ja suullisen tulkkauksen tutkimuksen perinteet ovat varsin erilaiset, minkä vuoksi niitä käsitellään seuraavassa ensin erikseen. Molemmissa kyse on kuitenkin pohjimmiltaan kielten- ja kulttuurienvälisen viestinnän välittämisestä. Myöskään raja kirjallisen ja suullisen välillä ei ole aina selvä. Esimerkiksi prima vista -tulkkauksessa tehdään kirjoitetusta lähdetekstistä valmistelematon suullinen käännös, tekstityksessä puolestaan käännetään puhetta kirjoitettuun muotoon.

\subsection{Kääntämisen tutkimus}

Kääntäminen toimintana on ikivanhaa, ja kääntämisen kysymyksiä on tarkasteltu kauan ennen kuin voi puhua varsinaisesta tutkimuksesta. Kääntämisen perinteisiä kysymyksiä ovat lähde- ja kohdetekstin suhde ja niiden vastaavuus sekä kääntämisen uskollisuus vs. vapaus (vrt. esim. Chesterman 2016 [I997]). Näiden kysymysten merkitystä länsimaisessa käännöstutkimuksessa ja kääntämistä koskevassa keskustelussa on selitetty uskonnollisten tekstien keskeisyydellä kääntämisen historiassa (esim. Prunč 2007). Toinen keskeinen alue on ollut kaunokirjallisuuden kääntäminen, jonka kysymyksiä on jo satojen vuosien ajan pohdittu.

Käännöksiä on tutkittu monilla tieteenaloilla: teologiassa on tutkittu Raamatun ja muiden pyhien tekstien käännöksiä, vertailevassa kirjallisuuden tutkimuksessa on tarkasteltu kirjallisuuden käännöksiä, ja 
kielitieteessä erityisesti kontrastiivinen tutkimus on ollut kiinnostunut käännöksistä. Käännöstiede omana tieteenalana on varsin nuori; sen katsotaan syntyneen I900-luvun loppupuoliskolla, jolloin se irtaantui keskeisistä emotieteistä, kieli- ja kirjallisuustieteistä (käännöstieteen historiasta ks. esim. Munday 20ı2; Prunč 2007).

Kielitieteen piirissä syntyi niin sanottu lingvistinen käännöstiede I960-luvulla (mm. Catford I965). Taustalla oli usko konekääntämiseen ja pyrkimys luoda kieliparien välille käännöksiä tuottavia sääntöjä, käännöskielioppeja. Tarkastelu kohdistui lähinnä sanatasolle, eikä lausetta suurempia kokonaisuuksia juuri huomioitu. Kääntäminen nähtiin mekaanisena korvaamisena, jossa yhden kielen ilmaisu oli suoraviivaisesti toisinnettavissa toisen kielen ilmaisulla. Keskeinen käsite oli ekvivalenssi (vastaavuus), jota luokiteltiin eri tavoin (esim. Koller I979). Tekstilingvistiikan myötä tarkastelu siirtyi laajempiin kokonaisuuksiin, myös tekstien funktioihin sekä viestintään ja viestin vastaanottajiin. Esimerkiksi Eugene Nida (i964), jonka ajattelun taustalla oli Raamatun kääntäminen, erotti muodollisen ja dynaamisen ekvivalenssin ja korosti jälkimmäisen merkitystä: muodollinen tarkka käännös on usein jäykkä, kun taas dynaamisesti ekvivalentti käännös pyrkii saamaan käännöksen vastaanottajassa saman vaikutuksen kuin lähdeteksti on saanut vastaanottajassaan, ja tällainen käännös voi vaatia suuriakin kulttuurisia muutoksia. Ekvivalenssi on käännöstieteen keskustelluimpia ja kiistellyimpiä käsitteitä, jota myös uudempi tutkimus on lähestynyt eri näkökulmista (ks. esim. Pym 20Io).

Käännöstieteen kehityksessä omaksi tieteenalaksi tärkeä tekijä oli James Holmesin (2000 [1972]) alun perin 1972 esittämä systemaattinen näkemys tieteenalasta nimeltä Translation Studies, sen rakenteesta ja osa-alueista (perusjakona descriptive translation studies ja theoretical translation studies tai käännösteoria, myöhemmin näistä "puhtaan" käännöstieteen suunnista erotettiin applied translation studies). Merkittävää oli niin ikään painopisteen siirtyminen lähdeteksteistä käännöksiin; käännösorientoituneisuutta edustavat käännöstieteessä edelleenkin keskeiset suuntaukset: funktionaaliset käännösteoriat ja deskriptiivinen käännöstutkimus.

I980-luvulla syntyneet funktionaaliset käännösteoriat, kuten Hans Vermeerin skopos-teoria (Reiß \& Vermeer I984) ja Justa Holz-Mänttärin 
translatorisen toiminnan teoria (I984), korostavat kääntämistä tavoitteellisena toimintana, jossa ensisijaista on sen tarkoitus käännöksen vastaanottaja mukaan lukien. Kääntäjä on ammattimainen toimija, joka ei vain koodaa uudelleen sanoja vaan tuottaa tekstejä kulttuurienväliseen viestintään kulloisenkin toimeksiannon ja tilanteen vaatimusten mukaisesti. Siten käännöksen laatimiseen vaikuttavat muutkin seikat kuin lähdeteksti, esimerkiksi kohdekulttuurin lait, normit ja konventiot. Lisäksi translatoriseen toimintaan liittyy paljon muutakin kuin varsinainen kääntäminen: tiedonhankinta, tekstien tarkistus ja yhteistyö asiakkaiden ja muiden tekstin tuottajien kanssa. Tekstien multimodaalisuus, joka vasta myöhemmässä tutkimuksessa on tullut tärkeäksi huomioon otettavaksi näkökulmaksi, oli mukana jo Holz-Mänttärin teoriassa. Funktionalistit tulivat kielitieteen piiristä, ja heidän tutkimuksensa kohdistuivat erityisesti erikoisalojen ja käyttötekstien kääntämiseen, vaikka esimerkiksi Vermeer halusi luoda yleisen käännösteorian, joka koskee kaikkea kääntämistä.

Deskriptiivinen käännöstutkimus, jonka keskeisiä vaikuttajia oli Gideon Toury (I995), on puolestaan lähtöisin kirjallisuudentutkimuksen puolelta. Touryn kiinnostuksensa kohteena oli alun perin kirjallisuuden kääntäminen. Esimerkiksi polysysteemiteoria on kiinnostunut käännösten asemasta kohdekulttuurin kirjallisuuden systeemien verkostossa (Even-Zohar I990). Deskriptiivisellä käännöstutkimuksella on merkittävä sija nykyisessä käännöstieteellisessä tutkimuksessa tekstilajeihin katsomatta. Kun funktionalistit pyrkivät antamaan kriteereitä hyvälle käännökselle, deskriptiivisessä käännöstutkimuksessa tavoitteena on kuvata, millaisia käännökset ovat, ja selittää, miksi ne ovat sellaisia kuin ovat. Deskriptiivisen käännöstutkimuksen tutkimuskohteita ovat olleet muun muassa kääntämisen normit ja lainalaisuudet, ns. käännösuniversaalit (ks. tarkemmin luku 3.2.).

I980-luvulta lähtien käännöstiede on nopeasti kehittynyt ja laajentunut. 2000-luvun merkittäviä suuntauksia on muun muassa kääntämisen sosiologia, joka kiinnittää huomion kääntäjään ja toimintaympäristöön. Tutkimuskohteena on myös kääntämisen (ja tulkkauksen) historia. Kognitiivinen käännöstiede puolestaan tutkii käännösprosessia, sitä mitä kääntäjän päässä tapahtuu, kun hän kääntää. Viime aikojen sosiokognitiivinen suuntaus, joka näkee kognition kehollisena ja tilannesidonnaisena, 
tarkastelee käännösprosessin tutkimuksessa "laajennettua kääntämistä" (engl. extended translation) ottaen huomioon kääntäjien teknologisen ja sosiaalisen työskentely-ympäristön, myös ergonomian (Risku, Rogl \& Milosevic 20I7). Teknologian kehityksen myötä omiksi ja kasvaviksi alueiksi ovat muodostuneet av-kääntämisen tutkimus ja käännösteknologia. Multimodaalisuuden kysymykset ja intersemioottinen kääntäminen ovat niin ikään kasvavia alueita. Nykyisissä monikielisissä yhteiskunnissa ylipäätään kysymys siitä, mikä tekee tekstistä käännöksen, mikä on lähdeteksti ja kuka on kääntäjä, ovat yhä monimutkaisempia, mikä vaatii tutkimukselta uusia lähestymistapoja, aineistoja ja menetelmiä. Käännöstieteen alueellinen laajentuminen on nostanut esiin myös sen, että länsimainen käsitys käännöksistä ja kääntämisestä on yksipuolinen ja suppea.

\subsection{Tulkkauksen tutkimus}

Koska puhuttu kieli ja keskustelu ovat ensisijaisia vuorovaikutuksen keinoja, suullista tulkkausta on esiintynyt paljon ennen kirjallista kääntämistä. Tulkkauksen systemaattinen tutkimus on kuitenkin alkanut myöhemmin kuin kääntämisen tutkimus. Tulkkauksen tutkimuksen yhtenä merkittävimpänä pioneerina on pidetty Danica Seleskovitchia, jonka ensimmäiset konferenssitulkkausta koskevat julkaisut ilmestyivät I960-luvulla. Hänen kehittämänsä tulkinnan teoria (ra. théorie du sens) näkee tulkkauksen sanoman ymmärtämisenä ja tulkitsemisena; erityisen tärkeää on tulkin yleistieto ja tieto tulkattavasta asiasta (Seleskovitch \& Lederer I989). Teoria nojautui psykologiaan ja poikkesi selvästi kääntämisen puolella vallinneesta lingvistisestä lähestymistavasta, jossa sanoja koodattiin uudelleen kielestä toiseen.

Tulkkauksen tutkimuksen kohteena oli aluksi yksinomaan konferenssitulkkaus, ja ammatilliset ja koulutuskysymykset olivat keskeisiä. Tutkijat, kuten Seleskovitch, olivat itse konferenssitulkkeja. Pitkälti intuitioon perustuva tutkimus oli preskriptiivistä; siinä annettiin ohjeita tulkkien toiminnalle. (Gile 2009.) Empiirinen ja kokeellinen tutkimus alkoi I990-luvulla. Kohteena oli edelleen konferenssitulkkaus, mutta tutkimukseen vaikuttivat keskeisesti kognitiivinen psykologia ja 
neurotieteet sekä näitä lähellä olevat kielitieteen haarat psykolingvistiikka ja neurolingvistiikka (ks. Psyko- ja neurolingvistiikka tk.). Tutkijoita kiinnostivat erityisesti kognitiiviset kysymykset, kuten informaation prosessointi, kahdella kielellä tapahtuva puheen samanaikainen vastaanottaminen ja tuottaminen, ennakointi, muisti, kognitiivinen kuormitus, tulkkausstrategiat (Gile I997) ja aivotoiminta (Tommola, Laine, Sunnari \& Rinne 2000) (ks. myös Englund Dimitrova \& Hyltenstam 2000).

Käännöstutkimuksen puolella jalansijaa saaneet tekstintutkimus, funktionaaliset teoriat ja kohdetekstiorientoituneisuus vaikuttivat myös tulkkauksen tutkimuksessa. Pöchhacker (2004) on kutsunut näitä suuntauksia, joille yhteistä on kiinnostus tekstuaaliseen tuotteeseen, TT-paradigmaksi (engl. target-text-oriented translation-theoretical). Konferenssitulkkauksesta tutkimus laajeni vähitellen dialogitulkkaukseen.

Vasta I990-luvun lopussa ja 2000-luvulla tutkimus kiinnostui siitä tulkkauksesta, joka tapahtuu kansallisessa kontekstissa erilaisissa sosiaalisissa tilanteissa, kuten asioimistulkkauksesta eli tulkkauksesta viranomaisasioinnissa ja terveydenhuollossa sekä oikeustulkkauksesta. Oikeustulkkauksen tutkimuksessa keskeisiä kysymyksiä ovat olleet muun muassa tarkkuus ja tulkin puolueettomuus. Kun sekä oikeusettä asioimistulkkauksessa kyse on vuorovaikutuksesta, tulkkivälitteinen vuorovaikutus ja siihen liittyvät kysymykset, kuten tulkin rooli, ovat nousseet tutkimuksen keskiöön (mm. Wadensjö ı998, ks. myös luku 3.3.). (Tulkkauksen tutkimuksen historiasta ja painopisteistä ks. Pöchhacker 2004; Rouhe 20I7.)

Vaikka kääntämisen ja tulkkauksen tutkimuksen perinteet ja lähtökohdat eroavat, I990-luvulta lähtien on myös etsitty yhteistä pohjaa. Saksalaisella kielialueella vaikutusvaltaiset funktionaaliset käännösteoriat saivat tulkkauksen tutkimuksessa huomion kiinnittymään paitsi kokonaistilanteeseen ja toimintaan myös tekstilingvistisiin kysymyksiin. Käännöstieteessä vaikuttava sosiologinen suunta näkyy myös tulkkauksen tutkimuksessa; kohteena voi olla esimerkiksi tulkin status tai tulkkauksen historia. Deskriptiivisessä käännöstieteessä ja käännettyjen tekstien tutkimuksessa suosittu korpustutkimus on saanut jalansijaa myös tulkkauksen tutkimuksessa. Yhteisiä kysymyksiä ovat myös koulutukseen liittyvät ja ammatilliset kysymykset sekä laadun määrittely. 


\section{Käännöstieteen tutkimuskohteita, metodeja ja aineistoja}

\subsection{Tekstintutkimus: käännökset ja tulkkeet}

Monen maan kirjallisuuden historia alkaa käännöskirjallisuudesta, ja käännöstieteellisen tutkimuksen historiallinen ydin on tekstintutkimusta. Käännettyjen tekstien osalta nykytutkimus koskee tekstilajien koko kirjoa uskonnollisten tekstien käännöksistä käännettyihin verkkoteksteihin, kaunokirjallisuudesta käyttöohjeisiin, erikoisalojen teksteistä lastenkirjallisuuteen, laki- ja säädösteksteistä tv-tekstityksiin, tuotepakkausselostuksista dubbaukseen, tietokonepelien käännöksistä oopperatekstityksiin, laulujen sanoituksista sarjakuviin, käännetystä kielimaisemasta lääkepakkausteksteihin jne. Ei liene tekstilajia, jota ei olisi käännetty. Tutkijat ovat perinteisesti koostaneet omiin tutkimustarkoituksiinsa tarkastelemansa tekstilajin käännöksistä aineistoja ja analysoineet niitä manuaalisesti, ja nämä aineistonkeruu- ja analyysimenetelmät ovat edelleen ajankohtaisia ja taajaan käytössä. Oman tutkimussuuntauksensa muodostaa korpuslingvistinen käännettyjen tekstien tutkimus, jossa tutkittava tekstiaineisto on saatettu sähköiseen muotoon. Sähköisten korpusten tutkimusta esitellään erikseen seuraavassa luvussa 3.2. Sähköisiä ja ei-sähköisiä aineistoja käytetään usein myös rinnakkain.

Käännettyjä tekstejä ei tyypillisesti tutkita sellaisenaan, vaan tutkija valitsee jonkin yksittäispiirteen tai ilmiön ja tarkastelee sen esiintymistä käännetyissä teksteissä. Tekstilajista riippuen tutkimus voi kohdistua eri ilmiöihin; esimerkkeinä mainittakoon mm. erisnimien, kulttuurispesifisten ilmausten eli reaalioiden, varieteettien, monikielisyyden, sanaleikkien, tabusanojen, huumorin, tyylipiirteiden, kieliopin ilmiöiden tai lähettäjä-vastaanottaja-konstellaatioiden kääntäminen. Käännöstieteellinen tutkimus tuottaa paljon uutta tietoa näistä ilmiöistä, mutta varsinainen tavoite on sen kuvaaminen, mitä ikkunoita käännökset avaavat kääntämiseen, kääntäjän työhön tai kohdekulttuuriin.

Menetelmällisesti ei-sähköisten tekstiaineistojen hyödyntäminen tarkoittaa ilmiöiden manuaalista poimintaa teksteistä, luokittelua ja 
mahdollisesti myös muiden erilaisten analyysimenetelmien käyttöä (esim. lähiluku, diskurssianalyysi, keskustelunanalyysi, kategoria-analyysi, sisällönanalyysi, retoriikan ja tekstilingvistiikan teoriat, kieliopin erilaiset kuvausmallit jne.). Keskeinen menetelmä on vertailu: kääntäjän käännösratkaisuja vertaillaan tyypillisesti lähdetekstiin, toisenkielisiin käännöksiin tai aikaisemmin tai myöhemmin ilmestyneisiin samankielisiin käännöksiin. Julkaistut käännökset eivät heijastele vain kääntäjän ratkaisuja vaan myös kustannustoimittajan, kielentarkastajan tai muiden mahdollisten toimijoiden "sormenjälkiä". Mahdollista onkin vertailla julkaistua käännöstä myös julkaisemattomiin käännösversioihin ja tarkastajien kommentteihin. Vertailun menetelmiä kielentutkimuksen eri alueilla käsitellään kattavasti Kolehmaisen, Miestamon ja Nordlundin (20I3) toimittamassa teoksessa.

Vertailu lähdetekstiin mahdollistaa yhtäläisyyksien ja erojen paikantamisen, ja sen avulla on mahdollista kuvata käännösstrategioita, kääntäjän kohdekielisiä ratkaisuja lähdetekstin ilmiöihin. Käännösstrategiat heijastavat kääntämisessä ja kohdekulttuurissa kulloinkin vallitsevia arvoja, ideologioita ja normeja. Tutkimuksessa on esimerkiksi kysytty, miksi puhekielen piirteet, tietyt kerronnan keinot, kirosanat, uskonnolliset tai poliittiset viittaukset ja seksuaalisten vähemmistöjen esittäminen saattavat kadota tai muuttua käännöksissä. (Suomalaisesta kääntämisen normien ja ideologioiden tutkimuksesta ks. esim. Koskinen \& Paloposki 20I5; Kujamäki ı998; Kuusi 20ıг; Tiittula \& Nuolijärvi 20I3.) Käännösversioiden keskinäinen vertailu taas avaa näkökulmia kääntäjän työskentelyyn ja käännösprosessiin, ja opiskelijakäännösten vertailu ammattilaisten tuotoksiin tuo tietoa kääntäjäkompetenssin kehittymisestä sekä sen luonteesta (ks. luku 3.3.). Multimodaalisten lähdetekstien vertailu niiden käännöksiin tuo tietoa kääntäjän työstä, siitä, miten kielen ulkopuoliset seikat, kuten kuvan tai äänen ja sanan suhde, vaikuttavat käännettyyn lopputulokseen esimerkiksi lasten kuvakirjojen, verkkotekstien tai tv-sarjojen ja elokuvien käännöksissä. Käännettyjä tekstejä on vertailtu lähdeteksteihin myös laadun näkökulmasta. Ajankohtainen tutkimus korostaa kuitenkin, että laatu ei ole ainoastaan käännöksen vaan myös käännösprosessin ominaisuus. Se, millaisin reunaehdoin, millaisissa ympäristöissä ja tuotantoketjuissa käännöksiä tuotetaan, vaikuttaa käännöksen laatuun (ks. esim. Abdallah 20I2). 
Käännöstieteellinen tekstintutkimus voi kohdistua myös teksteihin, jotka eivät ole käännöksiä. Tällaisia tekstejä ovat esimerkiksi käännöksiä ja kääntämistä kommentoivat paratekstit: ne ovat joko teoksen yhteydessä esiintyviä teosta kommentoivia tekstejä (esim. otsikko, esipuhe, jälkisanat, viitteet) tai teosta siitä erillään kommentoivia tekstejä (esim. päiväkirjamerkinnät, kirja-arviot, kirjeenvaihto, haastattelut). Niiden avulla on tutkittu esimerkiksi kääntämisen ideologiaa, käännösprosessia sekä kääntäjien verkostoja ja toimintaa (ks. esim. Kemppanen 20ıг; Paloposki 2007).

Tulkkausaineistojen luonne poikkeaa osin käännetyistä aineistoista. Suullinen tulkkaus on tyypillisesti ainutkertainen tilanne, jossa syntyvään tulkkeeseen tulkin ei ole mahdollista palata: tulketta ei voi jälkikäteen hioa, korjata tai muokata. Tulkkauksen tutkimuksessa tulke toimiikin tutkijalle usein ikkunana tulkkausprosessin kognitiiviseen, psykolingvistiseen ja sosiaaliseen ulottuvuuteen: tulkin muistiin, tulkkauksen kuormittavuustekijöihin sekä tulkin toimintaan välittäjänä eri osapuolia sisältävissä tilanteissa. Tulkeaineistoja on taltioitu erilaisista aidoista tulkkaustilanteista tulkkauslajeittain (simultaani-, konsekutiivi-, konferenssi-, oikeus-, asioimistulkkaus jne.) mutta myös tutkimusta varten järjestetyistä kokeellisista tulkkaustilanteista ja tulkkiopiskelijoiden oppimistilanteista.

Tulkkauksessa analyysi on kohdistunut lähdekielisen puheen ominaisuuksiin sekä siihen, kuinka lähdepuhe vaikuttaa tulkkeeseen (kieltenväliset erot, puheen ja puhujien piirteet). Tutkijat ovat tarkastelleet esimerkiksi tulkkeessa esiintyviä toistoja, korjauksia, lisäyksiä, poistoja, viiveitä ja taukoja sekä niiden syitä. Tutkittujen piirteiden avulla on lähestytty esimerkiksi tulkkausstrategioita, tulkkauksen laatua, tarkkuutta ja sujuvuutta, tulkkausprosessia, tulkin roolia ja teknisten ratkaisujen vaikutusta (esim. etätulkkauksessa). (Suomalaisesta tutkimuksesta ks. esim. Isolahti 20I4; Rouhe 20I7; Vik-Tuovinen 2006; Vuorikoski 2004; tulkkauksen tutkimuksesta ks. myös luku 3.3.)

Sekä käännökset että tulkkeet ovat vain yksi osa käännös- tai tulkkausprosessia. Molempiin prosesseihin vaikuttavat esimerkiksi toimeksianto, vuorovaikutustilanne, valmistautuminen ja toimijoiden etukäteen saama valmistautumismateriaali. Koko kääntämis- tai tulkkausprosessi ei siten ole tutkijan saavutettavissa pelkän käännöksen tai tulkkeen analyysin avulla. 
Käännettyjen tekstien ja tekstilajien tutkimuksesta:

Kinnunen, Tuija. 2012. Käännöstiede. Julkaisussa: Heikkinen, Vesa, Voutilainen, Eero, Lauerma, Petri, Tiililä, Ulla \& Lounela, Mikko (toim.) Genreanalypsi - tekstilajitutkimuksen käsikirja. Helsinki: Gaudeamus Helsinki University Press, 581-586.

Saldanha, Gabriela \& O'Brien, Sharon. 2013. Research Methodologies in Translation Studies. London: Routledge.

\section{Tulkkeiden tutkimuksesta ja tulkkauksen historiasta:}

Pöchhacker, Franz. 2004. Introducing Interpreting Studies. London: Routledge.

Rouhe, Olga. 2017. Kieliopin rakenne-erojen vaikutus suomi-venäjäsimultaanitulkkauksen sujuvuuteen. Publications of the University of Eastern Finland. Dissertations in Education, Humanities, and Theology 102. Joensuu: Itä-Suomen yliopisto. Saatavissa: http://urn.fi/URN:ISBN:978-952-61-2434-6.

Vuorikoski, Anna-Riitta. 2004. A Voice of its Citizens or a Modern Tower of Babel? The Quality of Interpreting as a Function of Political Rhetoric in the European Parliament. Acta Universitatis Tamperensis 985. Tampere: Tampereen yliopisto. Saatavissa: http://tampub.uta.fi/bitstream/handle $/ 10024 / 67348 / 951-44-5878-8$. pdf? sequence $=1 \&$ isAllowed $=y$.

\section{Vertailusta tutkimusmenetelmänä:}

Kolehmainen, Leena. 2013. Käännöstiede ja kontaktilingvistiikka kohtaavat. Julkaisussa: Kolehmainen, Leena, Miestamo, Matti \& Nordlund, Taru (toim.) Kielten vertailun metodiikka. Suomalaisen Kirjallisuuden Seuran Toimituksia 1387. Helsinki: Suomalaisen Kirjallisuuden Seura, 420-460.

Kujamäki, Pekka. 2013. Vertaileva kääntäjä, vertaileva tutkija: kieltenvälinen vertailu käännöstieteessä. Julkaisussa: Kolehmainen, Leena, Miestamo, Matti \& Nordlund, Taru (toim.) Kielten vertailun metodiikka. Suomalaisen Kirjallisuuden Seuran Toimituksia 1387. Helsinki: Suomalaisen Kirjallisuuden Seura, 355-395. 


\subsection{Korpuslingvistinen käännösten ja tulkkeiden tutkimus}

Edellisessä luvussa havainnollistetut käännöksiä tai tulkkeita sisältävät aineistot on mahdollista saattaa sähköiseen muotoon, jolloin niitä voi analysoida erilaisten automaattisten työkalujen ja ohjelmien avulla. Suuria sähköisiä kirjoitetun tai puhutun kielen aineistoja kutsutaan yleensä korpuksiksi (ks. Korpusaineistot tk.). Kuva I havainnollistaa käännöstieteellisen tutkimuksen tärkeimpiä korpustyyppejä. Keskeiset termit, rinnakkaiskorpus (engl. parallel corpus) ja sen synonyyminä esiintyvä käännöskorpus (engl. translation corpus) sekä verrannollinen korpus (engl. comparable corpus), ovat pitkälti vakiintuneet, mutta on syytä olla tietoinen siitä, että termien käyttö ja merkitys vaihtelevat eri tutkijoiden kesken. Havainnollistamme seuraavassa näitä aineistoja ja niiden avulla tutkittuja kysymyksiä.

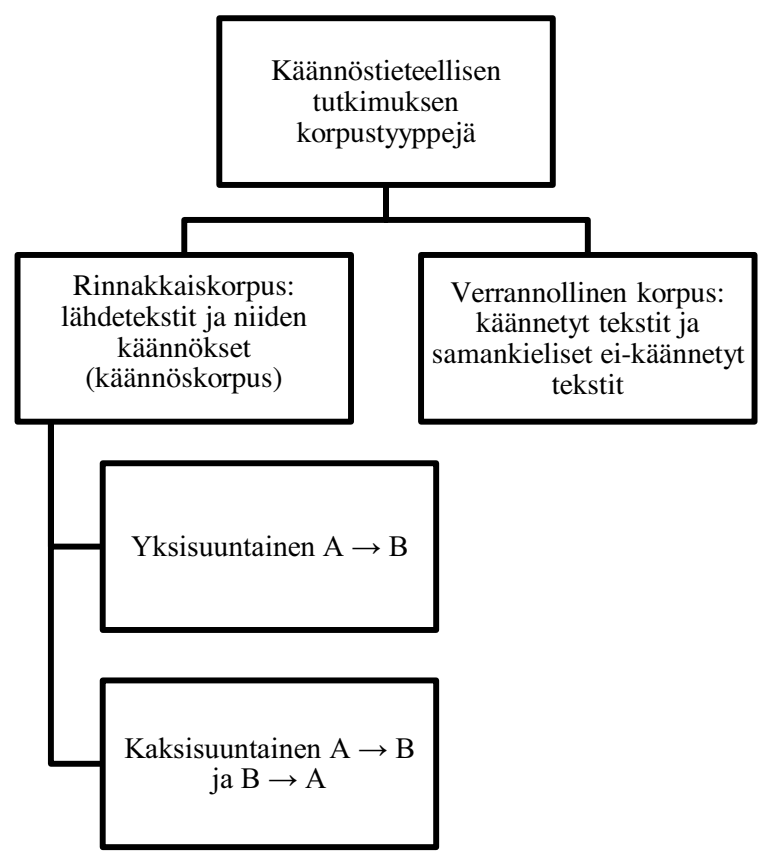

Kuva 1. Käännöstieteellisen tutkimuksen keskeiset korpustyypit. 
Rinnakkaiskorpuksilla eli käännöskorpuksilla tarkoitetaan yleensä kaksitai monikielisiä korpuksia, jotka koostuvat yhden kielen lähdeteksteistä ja niiden käännöksistä yhteen tai useampaan kieleen. Mahdollisesti mukana voi olla saman lähdetekstin useampia käännöksiä samaan tai eri kieliin. Rinnakkaiskorpus voi olla yksisuuntainen ja sisältää käännöksiä vain yhteen suuntaan tai kaksisuuntainen, jolloin mukana on käännöksiä kielestä A kieleen B ja kielestä B kieleen A. Kaksisuuntaisten rinnakkaiskorpusten pioneerina pidetään usein englanti-norjarinnakkaiskorpusta ${ }^{1}$ (Johansson 2007). Se koostuu englanninkielisistä lähdeteksteistä ja niiden norjannoksista sekä norjankielisistä lähdeteksteistä ja niiden englanninnoksista. Korpus mahdollistaa siten kieltenvälisen vertailun keskenään rinnakkaisten tekstien välillä (lähdetekstien vertailu käännöksiin) molemmissa suunnissa (englanti-norja, norjaenglanti) ja keskenään verrannollisten tekstien välillä (englanninkieliset vs. norjankieliset alkuperäistekstit, englanninkieliset vs. norjankieliset käännökset). Lisämahdollisuutena on yksikielinen alkuperäistekstien vertailu samankielisiin käännöksiin (englanninkieliset alkuperäistekstit vs. käännökset, norjankieliset alkuperäistekstit vs. käännökset).

Verrannolliset korpukset puolestaan koostuvat teksteistä, jotka eivät ole toistensa käännöksiä mutta ovat jollakin muulla tapaa vertailukelpoisia keskenään, esimerkiksi tekstilajiltaan. Käännöstieteessä verrannollisia korpuksia voidaan pitää I990-luvulla alkaneen korpuslingvistisen "buumin" yhtenä laukaisijana. Idea verrannollisista korpuksista palautuu Bakerin (I993; I996) artikkeleihin, joissa esiteltiin kokonaan uudenlainen aineistoasetelma: edellä esitellyn rinnakkaiskorpusten mahdollistaman lähdetekstien ja niiden käännösten vertailun sijaan käännettyjä tekstejä olisikin mahdollista vertailla myös samankielisiin ei-käännettyihin teksteihin. Verrannollisten korpusten tutkimuksessa alettiin keskittyä enemmän kohdeteksteihin, kun aiemmin keskityttiin lähdeteksteihin. Tunnettuja verrannollisia korpuksia ovat esimerkiksi Translational English Corpus ${ }^{2}$ (Laviosa I996), joka sisältää eri kielistä englantiin käännettyjä ja verrannollisia ei-käännettyjä englanninkielisiä tekstejä, ja Käännössuomen korpus (Mauranen 2000), joka koostuu eri kielistä suomeen käännetyistä ja ei-käännetyistä, ns. supisuomen teksteistä. Suomalainen YLE-korpus, joka lienee edelleenkin 
maailman suurin ruututekstikorpus, lukeutuu verrannollisiin korpuksiin. Se sisältää Ylen vuosina I992-2004 lähettämien tv-ohjelmien eri kielistä käännetyt tekstitykset ja kuulovammaisille katsojille suunnatut ei-käännetyt ohjelmatekstitykset. ${ }^{3}$ Tiedemannin Opus on rinnakkaiskorpus, joka käsittää internetistä kerättyjä käännöstekstejä, myös elokuvien ja tv-ohjelmien tekstityksiä. ${ }^{4}$

Korpuslingvistiset tutkimukset ovat pitkälti keskittyneet mahdollisten kääntämisen universaalien selvittämiseen. Hypoteesi kääntämisen universaaleista, kielellisistä piirteistä, jotka esiintyvät kieliparista riippumatta pikemminkin käännetyissä teksteissä kuin ei-käännetyissä ja joita kääntäminen erityisenä kielentuottamisprosessinaan aiheuttaa kohdeteksteihin, palautuu Bakerin (I993; I996) julkaisuihin. Kääntämisen universaaleja tai lakeja, jotka erottavat käännöksiä samankielisistä ei-käännetyistä teksteistä (Toury I995), on tutkittu korpuksissa tarkastelemalla esimerkiksi sana- ja sanemääriä ja leksikaalista variaatiota, mittaamalla lause- ja virkepituuksia, tutkimalla kollokaatioita (eli mitkä sanat esiintyvät tyypillisesti yhdessä) tai analysoimalla lukuisten erilaisten kielen yksiköiden, kuten pronominien, konjunktioiden, fraseologismien tai kieliopillisten rakenteiden, käyttöympäristöjä, funktioita ja esiintymistiheyksiä.

Kääntämisen universaaleiksi on ehdotettu mm. käännösten kielellistä eksplisiittistymistä (tendenssi lisätä käännetyn tekstin eksplisiittisyyttä esim. koheesiokytkennöillä ja selityksillä), yksinkertaistumista ja normaalistumista (viimeisintä kutsutaan vaihtoehtoisesti myös konventionaalistumiseksi, standardisoitumiseksi tai tasaantumiseksi). Kollokaatioiden on havaittu olevan epätyypillisiä käännöksissä, ja kielellisten yksiköiden frekvenssien on huomattu olevan poikkeuksellisia. Esimerkiksi kieliparikohtaiset kohdekielen ns. vastineettomat ainekset näyttävät olevan harvinaisempia kuin ei-käännetyissä teksteissä tai puuttuvan kokonaan. ${ }^{5}$

Kääntämisen universaalien tutkimuksessa rinnakkaiskorpusten käyttö on jatkunut verrannollisten korpusten rinnalla. Tämä on aiheuttanut joskus käsitteellistä sekaannusta, ja aina ei ole täysin selvää, mitä tutkijat täsmälleen tarkoittavat. Chestermanin (2004) erottelu S- ja T-universaalien välille onkin selkiyttänyt keskustelua: $\mathrm{S}$-universaalit $(\mathrm{S}=$ source) 
viittaavat käännettyjen tekstien piirteisiin verrattuna niiden lähdeteksteihin. T-universaalit ( $\mathrm{T}=$ target $)$ taas tarkoittavat systemaattisia eroja kohdekielisten käännösten ja samankielisten ei-käännettyjen tekstien välillä. Kääntämisen universaalihypoteeseja on myös kritisoitu, ja kaikille ehdotetuille hypoteeseille on löydetty vastaesimerkkejä korpuksista, muita selityksiä tai vasta-argumentteja kääntämisen historiasta (ks. esim. Becher 20II; Kuusi 20ı6; Tiittula \& Nuolijärvi 20ı6).

Kääntämisen universaalien tutkimuksessa tavoitteena oli alun perin selvittää, mikä on käännetyille teksteille yhteistä lähdekielestä riippumatta ja mitä piirteitä kääntäminen omana erityisenä kielen tuottamisprosessinaan aiheuttaa. Mukana tarkastelussa on ollut kuitenkin alusta asti myös kysymys kieliparikohtaisista tai kieltenvälisistä typologisista eroista ja niiden vaikutuksesta käännettyjen tekstien kielellisiin piirteisiin (ks. esim. Cappelle \& Loock 20I7), interferenssistä eli lähdekieli- tai lähdetekstispesifisestä kontaktivaikutuksesta käännettyihin teksteihin (ks. esim. Mauranen 2004) sekä käännössuunnan vaikutuksesta (ks. esim. Evert \& Neumann 20I7). Tutkijat ovat myös kysyneet, mikä on tekstilajikohtaista, mikä kääntämiselle universaalia tekstilajista riippumatta (ks. esim. Delaere \& De Sutter 20I7). Lisäksi korpustutkijat ovat nostaneet esille muiden mahdollisten toimijoiden käännöksiin jättämät jäljet - kääntäminen on sosiaalinen tapahtuma, jossa lopputulokseen vaikuttavat kääntäjien lisäksi kustannustoimittajat, editoijat ja kielentarkastajat. Korpuksiin taltioidut käännetyt tekstit eivät siten välttämättä kerro vain kääntäjän ratkaisuista. (Kruger 20I7.) Vaihtelua aiheuttaa myös se, kenen käännöksestä on kyse. Kääntäminen voi tapahtua kääntäjän äidinkieleen tai vieraaseen kieleen - ja aina ei ole edes selvää, onko kyse äidinkielestä vai vieraasta kielestä (ks. esim. Pokorn 2005). Yhteenvetona kääntämisen universaalipiirteiden tutkimuksesta voi todeta, että nykykorpustutkimuksen valossa käännettyjen tekstien mahdolliset erityisyydet näyttäytyvät monimutkaisina piirteiden kimppuina, jotka voivat johtua useasta samanaikaisesti vaikuttavasta tekijästä, ei pelkästään käännösprosessista.

Korpusten avulla on tutkittu myös tekstien ideologiaa: keskeisenä menetelmänä tässä tutkimuksessa on ollut avainsana-analyysi. Avainsanalla tarkoitetaan kielenainesta, jonka esiintymistiheys aineistossa poikkeaa 
tilastollisesti merkitsevästi vertailuaineistosta. Poikkeuksellinen esiintymistiheys kertoo esimerkiksi käännettyjen tekstien näkökulmapiirteistä ja diskursiivisista erityispiirteistä tai eroista vertailuaineistoihin verrattuna (ks. esim. Kemppanen 2008; Probirskaja 2009; Laviosa, Pagano, Kemppanen \& Ji 20I7). Automaattisten korpuslingvististen menetelmien rinnalla tutkijat hyödyntävät usein tilastollisia menetelmiä (ks. Määrällinen korpuslingvistiikka tk.).

Kielenoppimisen tutkimuksessa koostettuihin oppijankielen korpuksiin taas rinnastuvat käännöstieteilijöiden opiskelijakäännöskorpukset, joita esitellään esimerkiksi Castagnolin, Ciobanun, Kunzin, Küblerin ja Volanschin (20II) artikkelissa. Alan terminologia ei ole vielä vakiintunut vaan vaihtelee (engl. translation learner corpus, learner translator corpus, student translation corpus). Opiskelijakäännöskorpusten avulla on mahdollista tutkia esimerkiksi opiskelijoiden käännöskompetenssia ja sen kehittymistä ja vertailla sitä ammattikääntäjien kompetenssiin (ks. esim. Englund Dimitrova 2005).

Sähköiset tulkkauskorpukset on mahdollista jakaa samalla tavalla lähdetekstejä ja niiden tulkkeita sisältäviin kaksi- tai monikielisiin rinnakkaiskorpuksiin sekä verrannollisiin tulkkausta ja samankielistä ei-tulkattua vuorovaikutusta sisältäviin korpuksiin (ks. esim. Bendazzoli 20I5; Bendazzoli 20I8; Bernardini, Ferraresi, Russo, Collard \& Defrancq 20I8; Shlesinger I998). Shlesinger (I998, 3) korostaa, että ideaalitilanteessa molemmat tulkkauskorpukset sisältävät lisäksi kohdekielen käännettyjä tekstejä. Tällainen korpuskonstellaatio mahdollistaa sen tunnistamisen, mikä on nimenomaan tulkkaukselle tyypillistä ja erottaa sitä kääntämisestä. Tulkkauskorpukset eivät ole kehittyneet samaan tahtiin kirjoitetun kielen käännöksiä sisältävien korpusten kanssa, niitä ei ole saatavilla yhtä paljon, eivätkä ne ole yhtä suuria. Syy on ilmeinen: suullisen vuorovaikutuksen video- tai äänitaltioiminen, puheen litterointi ja paralingvististen keinojen merkintä litteraattiin on työläämpää kuin kirjoitettujen tekstien työstäminen.

Tulkkausmenetelmä ja -tilanne ovat keskeisimmät seikat, jotka vaikuttavat tulkkaukseen. Tästä syystä tulkkauskorpukset edustavat usein kulloinkin vain yhtä tai muutamaa tulkkausmenetelmää ja -tilannetta. Esimerkkeinä olemassa olevista sähköisistä tulkkauskorpuksista 
mainittakoon Euroopan parlamentin kokousten englanti-italia-espanjasimultaanitulkkauskorpus EPIC (The European Parliament Interpreting Corpus) ${ }^{6}$ (Monti, Bendazzoli, Sandrelli \& Russo 2005), monikielinen ComInDat (Community Interpreting Database) ${ }^{7}$, joka sisältää sekä lääkäri-potilas-asioimistulkkausta että oikeustulkkausta (Angermeyer, Meyer \& Schmidt 20I2), ja englanti-italia-simultaanitulkkauskorpus FOOTIE (Football in Europe) jalkapallon lehdistökonferensseista (Sandrelli 20I2).

Käännösten korpuslingvistiseen tutkimukseen on saatavilla lukuisia johdanto- ja kokoomateoksia.

Ajankohtaisia johdantoteoksia käännöstieteellisten korpusten kokoamisesta, annotoinnista ja korpuslingvistisestä analyysista:

Mikhailov, Mikhail \& Cooper, Robert. 2016. Corpus Linguistics for Translation and Contrastive Studies: A Guide for Research. Abingdon: Taylor $\&$ Francis.

Zanettin, Federico. 2012. Translation-Driven Corpora: Corpus Resources for Descriptive and Applied Translation Studies. Manchester: St. Jerome.

Ajankohtaisia kokoomateoksia käännösten korpuslingvistisestä tutkimuksesta:

Delaere, Isabelle, Lefer, Marie-Aude \& De Sutter, Gert (toim.). 2017. Empirical Translation Studies: New Methodological and Theoretical Traditions. Berlin: De Gruyter Mouton.

Hansen-Schirra, Silvia, Neumann, Stella \& Steiner, Erich (toim.). 2012. Cross-Linguistic Corpora for the Study of Translations. Insights from the Language Pair English-German. Berlin: De Gruyter Mouton.

Ji, Meng (toim.). 2016. Empirical Translation Studies: Interdisciplinary Methodologies Explored. Sheffield: Equinox. 
Ji, Meng, Hareide, Lidun, Li, Defeng \& Oakes, Michael (toim.). 2017. Corpus Methodologies Explained: An Empirical Approach to Translation Studies. London: Routledge.

Kruger, Alet, Wallmach, Kim \& Munday, Jeremy (toim.). 2013. Corpus-based Translation Studies: Research and Applications. London: Continuum.

Laviosa, Sara, Pagano, Adriana, Kemppanen, Hannu \& Ji, Meng. 2017. Textual and Contextual Analysis in Empirical Translation Studies. Singapore: Springer.

Oakes, Michael P. \& Ji, Meng (toim.). 2012. Quantitative Methods in Corpus-based Translation Studies: A Practical Guide to Descriptive Translation Research. Amsterdam: John Benjamins.

\section{Katsauksia korpuslingvistiseen tulkkaustutkimukseen ja ajankohtaista tutkimusta:}

Bendazzoli, Claudio. 2015. Corpus-based research. Julkaisussa: Pöchhacker, Franz (toim.) Routledge Encyclopedia of Interpreting Studies. Florence: Taylor \& Francis, 132-135.

Russo, Mariachiara, Bendazzoli, Claudio \& Defrancq, Bart (toim.). 2018. Making Way in Corpus-based Interpreting Studies. Singapore: Springer.

Setton, Robin. 2011. Corpus-based interpreting studies (CIS). Julkaisussa: Kruger, Alet, Wallmach, Kim \& Munday, Jeremy (toim.) Corpus-based Translation Studies: Research and Applications. London: Continuum, 33-75. Shlesinger, Miriam. 1998. Corpus-based interpreting studies as an offshoot of corpus-based translation studies. Meta XLIII: 4, 1-8. Saatavissa: http://citeseerx.ist.psu.edu/viewdoc/download?doi=10.1.1.119.9115\&re$\mathrm{p}=\mathrm{rep} 1 \&$ type $=\mathrm{pdf}$.

Straniero Sergio, Francesco \& Falbo, Caterina (toim.). 2012. Breaking Ground in Corpus-based Interpreting Studies. Bern: Peter Lang. 


\subsection{Prosessin tutkimus}

Käännöstutkimuksessa painopiste on pitkälti ollut lopputuotteessa, käännöksissä, vaikka prosessi vaikuttaa olennaisesti käännöksen laatuun. Suuri osa tulkkauksen tutkimusta taas on ollut nimenomaan prosessin tutkimusta (vrt. luku 2.2.). Koska kirjallinen kääntäminen ja suullinen tulkkaus ovat erilaista toimintaa, myös niiden prosessien tutkimuksessa on eroja. Seuraavassa painopiste on aluksi kognitiivisessa prosessin tutkimuksessa ja erityisesti kääntämisessä, mutta otamme soveltuvissa kohdin myös tulkkauksen huomioon. Luvun lopussa on lyhyt katsaus tulkkauksen tutkimuksessa käytetyistä menetelmistä.

Prosessin tutkimuksen keskeisenä tavoitteena on pidetty kääntämisen kognitiivisten prosessien ymmärtämistä painopisteen ollessa yksittäisessä kääntäjässä. Sekä kääntämisen että tulkkauksen prosessi on tavallisesti jaettu kolmeen vaiheeseen: lähdetekstin ymmärtämiseen, kahden kielen välillä tapahtuvaan siirtoon ja kohdetekstin tuottamiseen. (Englund Dimitrova 20I6.) Prosessia voidaan kuitenkin tarkastella laajemmin, ja esimerkiksi Muñoz Martín (2OIO) erottaa käännösprosessissa kolme tasoa: Ensimmäinen taso käsittää käännösprosessin aikaiset mentaaliset tilat ja operaatiot. Toinen, ensimmäiseen kiinteästi liittyvä taso käsittää kääntämisen osatehtävät, kuten lukemisen, kirjoittamisen, tiedonhankinnan ja oikoluvun. Kolmas taso viittaa käännösprosessin tilanteisuuteen ja sisältää kaiken käännöstoimeksiantoon ja käännökseen liittyvän toiminnan ja kaikki mukana olevat toimijat alkaen toimeksiantajan kontaktista ja päättyen lopullisen käännöksen vastaanottoon (vrt. Holz-Mänttärin I984 translatorisen toiminnan malli). Tällä tasolla käännösprosessiin kuuluvat niin yhteistyö eri toimijoiden kanssa kuin monet ammattikääntämiseen liittyvät lisätehtävät, kuten projektinhallinta tai laskutus. Tarkastelemme tässä luvussa kahta ensimmäistä tasoa ja niitä tutkivaa kognitiivista suuntausta eli käännösprosessia suppeammassa mielessä. Kolmatta tasoa, joka laajentaa näkökulman eri toimijoihin ja toimintaympäristöön, käsittelemme seuraavassa luvussa.

Kognitiivisessa käännösprosessin tutkimuksessa huomio on kohdistunut muun muassa ongelmanratkaisuun ja päätöksentekoon sekä käännösstrategioihin. Keskeisiä kysymyksiä ovat niin ikään kompetenssi 
ja asiantuntijuus sekä niiden kehittyminen, esimerkiksi miten ammattikääntäjän toiminta eroaa kokemattoman kääntäjän toiminnasta tai miten kompetenssia voidaan mallintaa. Koska kääntäminen on aina sidoksissa sosiaaliseen kontekstiin, prosessin tutkimuksessa pyritään myös ymmärtämään sen vaikutusta. (Saldanha \& O’Brien 2013, I09.)

Varhaisimpia tutkimusmenetelmiä on introspektio, kääntäjän sanallinen raportti omasta prosessistaan. Raportti voi olla suullinen tai kirjallinen, ja se voidaan tuottaa tehtävää suoritettaessa tai sen jälkeen. Esimerkiksi kääntäjä voi pitää päiväkirjaa prosessin aikana tai hän voi kertoa prosessistaan käännöksen jälkeen. Jälkeenpäin tapahtuvaa retrospektiota voidaan käyttää myös tulkkauksen tutkimuksessa (esim. Vik-Tuovinen 2006; retrospektiosta käännösprosessin tutkimuksessa ks. Hansen 2006). Kognitiivisesta psykologiasta lainattu ääneen ajattelun menetelmä oli pitkään keskeinen kognitiivisen käännöstutkimuksen menetelmä. Siinä tehtävän suorittajaa pyydetään verbalisoimaan kaikki ajatuksensa tehtävän aikana ja puhe litteroidaan "ääneenajatteluprotokollaksi" (think-aloud protocol, TAP). Göpferich, Bayer-Hohenwarter, Prassl ja Stadlober (20II) ovat ehdottaneet menetelmän nimeksi käännösprosessiprotokollaa (translation process protocol, TPP) osoittamaan sitä, että protokolla ei sisällä vain kääntämisen aikaista puhetta vaan myös toimintaa prosessin aikana, kuten tiedonhakua.

Menetelmällä on tutkittu kääntäjien ongelmanratkaisua ja eri ryhmien välisiä eroja, kuten kokeneiden kääntäjien ja opiskelijoiden käännösprosessien eroja (esim. Jääskeläinen I999). Menetelmää on kritisoitu siitä, että ääneen ajattelu häiritsee käännöstyötä eikä ole luonnollista. Lisäksi kaikki toiminnot, erityisesti automatisoituneet ja heikosti tiedostetut, eivät ole verbalisoitavissa. Rinnalle on esitetty parityöskentelyssä syntyvää dialogista protokollaa (Kussmaul I995). Tällöin yhdessä työskentelevät kääntäjät keskustelevat käännösongelmista ja niiden ratkaisuista, ja nauhoitettu keskustelu analysoidaan (mm. Pavlović 20I3). On huomattava, että TAP ja dialoginen protokolla paitsi ovat eri menetelmiä myös kuvaavat erilaisia prosesseja (Jääskeläinen 20IIb, I9).

Ääneen ajattelu -metodin rinnalle on tullut muita menetelmiä työkalujen kehittyessä. Tietokoneen näppäintoimintojen tallennusohjelmalla saadaan talteen kaikki käännösprosessin aikana tapahtuvat 
kirjoitustoiminnot mukaan lukien hiiren liikkeet, tauot ja poistot. Näin voidaan tarkastella esimerkiksi sitä, miten kääntäjä jaksottaa kääntämistä sekä editoi ja korjaa tuotostaan. Käännöstieteellisessä tutkimuksessa on käytetty erityisesti Translog-ohjelmaa. Esimerkiksi tekstin segmentointia tutkittaessa on havaittu, että kokeneet kääntäjät prosessoivat laajempia yksiköitä kuin kokemattomat (Jakobsen 2003; Englund Dimitrova 2005). Taukoja analysoimalla voidaan myös tutkia kääntäjän tai post-editoijan kognitiivista kuormitusta (O’Brien 2006). Myös kuvaruuduntallennusohjelma, joka tallentaa tietokoneen näytön tapahtumat, mahdollistaa kirjoitusprosessin yksityiskohtaisen tutkimisen. Lisäksi tallennetuiksi tulevat sähköiset tiedonhaut, esimerkiksi elektronisten sanakirjojen käyttö. Kumpulainen (20I6) on tutkinut menetelmän avulla kääntäjäopiskelijoiden käännösprosessia, kuten käännösyksikön pituutta, korjauksia ja tiedonhakua. Hänen pitkittäistutkimuksensa kohteena on käännöskompetenssin kehittyminen.

Silmänliike- eli katseenseurantatutkimuksen avulla voidaan tutkia kääntäjän ja tulkin kognitiivista suoritusta ja kuormitusta prosessin aikana. Esimerkiksi Jakobsen ja Jensen (2008) tutkivat sitä, miten lähdetekstin lukeminen eroaa sen mukaan, onko tarkoituksena tavallinen tekstin ymmärtäminen vai valmistautuminen tekstin kääntämiseen ja käännetäänkö suullisesti (prima vista -kääntäminen) vai kirjallisesti. Koglin (20I5) puolestaan vertaili kognitiivista kuormitusta metaforien kääntämisessä ja niiden konekäännösten post-editoinnissa. Silmänliiketutkimusta voidaan soveltaa myös vaikkapa kuvailutulkkauksen tutkimuksessa sen selvittämiseen, miten näkevä tulkki identifioi ja erottaa kokonaisuudesta salientin informaation, joka on olennainen auditiivisen kertomuksen rakentamisessa sokealle vastaanottajalle (Kruger 20I2).

Käännösprosessin tutkimuksessa korostetaan nykyään triangulaatiota (ks. Johdannon luku I tk.): koska kyse on kompleksisista prosesseista, niiden ymmärtäminen vaatii eri menetelmien yhdistämistä. Monimenetelmäisyys mahdollistaa myös uudenlaisia tutkimuskysymyksiä, kun aiemmin tutkimus uusien työkalujen sovelluksessa on ollut enemmän metodilähtöistä. Esimerkiksi yhdistämällä silmänliike- ja näppäintoimintojen tutkimusta on päästy tarkastelemaan käännösprosessin keskeisten osien, lähdetekstin ymmärtämisen ja kohdetekstin tuottamisen, 
suhdetta (Dragsted 20I0). Erityisesti käännöskompetenssin tutkimuksessa ja mallintamisessa monimenetelmäisyys on tavallista, ja prosessin tutkimukseen yhdistetään myös lopputulosten eli lopullisten käännösten analyysi (esim. Englund Dimitrova 2005; Göpferich ja muut 20II; Kumpulainen 20I6; PACTE Group 20II).

Samalla kun kognitiivisen käännösprosessin tutkimuksen kohteet ovat laajentuneet, esiin ovat nousseet yhä enemmän metodiset kysymykset, toisin sanoen kysymykset siitä, miten prosessia ylipäätään voidaan tutkia. Myös tutkimusasetelmaan on kiinnitetty tarkempaa huomiota, esimerkiksi tutkittavien valintaan ja luokitteluun (miten esim. määritellään ammattikääntäjä). Tutkimus on usein monitieteistä, ja erityisesti kognitiotieteen ja tietojenkäsittelytieteiden asiantuntemus on tarpeen. (Kognitiivisesta käännöstutkimuksesta tarkemmin ks. esim. Shreve \& Angelone 20ıо; Risku 20I2.)

Prosessin tutkimus on usein myös kokeellista. Gilen (20I5) mukaan kokeelliset menetelmät sopivat hyvin käännös- ja tulkkaustutkimukseen, koska kääntämiseen ja tulkkaukseen vaikuttavat aina monet tekijät ja niitä sekä kääntämisen ja tulkkauksen ympäristöä on mahdollista kontrolloida ja muunnella ja tuotos on helposti määriteltävissä. Usein tutkimus on eksploratiivista (vähän tutkittua aluetta kartoittavaa, pilottitutkimusta) tai kvasikokeellista (kaikkia muuttujia ei kontrolloida tai manipuloida). Koeasetelmissa voidaan tutkia esimerkiksi käännössuunnan vaikutusta prosessiin. Tulkkauksen puolella suuri osa simultaanitulkkauksen tutkimuksesta on ollut kokeellista ja hypoteesien testausta, ja tutkimus on kohdistunut muun muassa muistiin, kielen prosessointiin ja kognitiivisen kuormituksen vaikutuksiin (Hale \& Napier 20I3).

Kokeellisen tutkimuksen ongelma on, että tilanne ei useinkaan ole aito - paitsi ehkä opiskelijoille, joita onkin usein käytetty tutkimuksissa. Esimerkiksi tutkija valikoi käännettävän tekstin, joka voi ammattikääntäjän näkökulmasta olla epäolennainen. Jos tehtävä ei ole aito, ammattikääntäjiä on vaikea motivoida paneutumaan kääntämiseen niin kuin he työskentelisivät aidossa toimeksiannossa. Käännösprosessin tutkimuksessa kiinnitetäänkin yhä enemmän huomiota ekologiseen validiteettiin eli siihen, että koetilanne vastaa tutkittavaa todellisuutta ja kokeen tulokset ovat yleistettävissä tositilanteisiin. Myös etnografisten 
menetelmien avulla pyritään parantamaan tähänastisen prosessitutkimuksen puutteita (ks. Lingvistinen etnografia toimintayhteisöissä tk.). Sosiokognitiivisessa lähestymistavassa käännösprosessin tutkimuksessa otetaan huomioon kääntäjän ja hänen ympäristönsä vuorovaikutus, johon sisältyy paitsi työkalujen käyttö myös esimerkiksi kontaktit kollegoihin ja asiakkaisiin (Risku 20I4; Risku ja muut 20I7). Tutkija voi videoida kääntäjää tämän työskennellessä omassa työympäristössään tai havainnoida ja tehdä muistiinpanoja. Muistiinpanojen tarkkuutta lisää, jos tutkija puhuu ne auki välittömästi havainnointitilanteen jälkeen sekä nauhoittaa ja litteroi puheensa (Risku 20I4). Bundgaardin, Paulsen Christensenin ja Schjoldagerin (2016) tutkimuksessa ihmisen ja koneen välisestä vuorovaikutuksesta käytettiin makrotason analyysissa etnografisia menetelmiä (havainnointia, haastatteluja, dokumenttien analyysia) ja mikrotason analyysissa kokeellisia menetelmiä (näppäin- ja kuvaruututallennusta, haastatteluja, kyselyjä).

Käännösprosessia voidaan tutkia myös tarkastelemalla eri käännösversioita ja muita käännöksiin liittyviä dokumentteja, kuten kääntäjien päiväkirjoja, kustantajien ja kääntäjien kirjeenvaihtoa ja muuta arkistomateriaalia (Munday 20I5). Tällainen tutkimus on osoittanut, että käännöksen takana voi olla hyvin monia toimijoita (Walker 20I7). Kääntäjien yhteistyö ja yhteiskääntäminen ei ilmiönä ole uusi, mutta se on saanut uusia muotoja sähköisten verkkotyökalujen myötä. Esimerkkinä tästä on käännösten joukkoistaminen, jossa vapaaehtoinen verkkoyhteisö tuottaa käännöksen. Yhteiskääntämistä on tutkittu muun muassa kyselyjen ja haastattelujen avulla (ks. tarkemmin Jiménez-Crespo 20I6). Mikäli käännöstä tuotetaan yhdessä samassa tilassa, prosessia voidaan tutkia myös multimodaalisen vuorovaikutuksen tutkimuksen keinoin (Hirvonen \& Tiittula 20I8).

Tulkkauksen tutkimuksessa Pöchhacker (2004, 64) erottaa kolme pääasiallista lähestymistapaa: kenttätutkimuksen, kyselyn ja kokeellisen tutkimuksen. Kenttätutkimuksessa aineistoa kerätään aidosta ympäristöstä havainnoimalla tai tallentamalla. Tulkkaustilanteiden tallentamiseen voi olla vaikea saada nauhoitus- ja erityisesti videointilupia, minkä vuoksi tutkija voi joutua turvautumaan pelkkiin muistiinpanoihin. Tällöin havaintojen ja muistiinpanojen systematiikkaan ja analyysiin on kiinnitettävä erityistä huomiota. Tallenteiden avulla ja diskurssi- ja 
keskustelunanalyyttisin metodein voidaan analysoida tulkkausvuorovaikutusta, esimerkiksi sitä, miten tulkki koordinoi vuorovaikutusta (Wadensjö I998) tai miten erilaiset tulkkausstrategiat vaikuttavat tulkattavien osallistumismahdollisuuksiin (Gavioli \& Baraldi 20II), tai tulkin ei-verbaalin viestinnän merkitystä (Mason 20I2). Lisäksi on mahdollista analysoida vuorovaikutuksen muiden osapuolten, kuten oikeustulkkauksessa tuomareiden ja asianajajien, toimintaa eli sitä, miten he työskentelevät tulkin kanssa ja tulkin välityksellä asiakkaan kanssa (Kinnunen 20I0; 20I3). Tavallisesta monikielisestä arkivuorovaikutuksesta ja työelämästä taltioidut tilanteet puolestaan tuovat ilmi, kuinka tulkkaus voi limittyä monikielisten osallistujien muuhun kielelliseen vuorovaikutukseen ja muihin rooleihin (Harjunpää 20I7; Koskela, Koskinen \& Pilke 20I7). Maallikkotulkkien tulkkeiden analyysi taas nostaa esiin sen, millaisia eettisiä ja laatuongelmia kouluttamattoman tulkin käyttö voi aiheuttaa (Pöchhacker \& Kadric I999).

Aitojen ja vertailukelpoisten tulkkausaineistojen puuttuessa on käytetty simuloituja tulkkaustilanteita. Tällöin tärkeää on, että osallistujat toimivat niissä rooleissa, joissa he toimivat ammatillisesti. Esimerkiksi näin on vertailtu poliisikuulustelujen kasvokkaista tulkkausta etätulkkaukseen (Braun \& Taylor 20II). Usein prosessia tutkitaan myös analysoimalla lähde- ja kohdekielisiä korpuksia (ks. luku 3.2.).

\section{Katsauksia käännösprosessin tutkimukseen ja metodikirjallisuutta:}

Englund Dimitrova, Birgitta. 2016. Translation process. Julkaisussa: Gambier, Yves \& Doorslaer, Luc van (toim.). 2010-2016. Handbook of Translation Studies Online. [verkkoaineisto]. Amsterdam: John Benjamins. Jääskeläinen, Riitta. 2011a. Studying the translation process. Julkaisussa: Malmkjær, Kirsten \& Windle, Kevin (toim.) The Oxford Handbook of Translation Studies. Oxford: Oxford University Press, 123-135.

Risku, Hanna. 2012. Cognitive approaches to translation. Julkaisussa: Chapelle, Carol A. (toim.) The Encyclopedia of Applied Linguistics. [verkkoaineisto]. DOI: 10.1002/9781405198431.wbealo145. 


\section{Ajankohtaisia kokoomateoksia käännösprosessin tutkimuksesta:}

Alvstad, Cecilia, Englund Dimitrova, Birgitta, Hild, Adelina \& Tiselius, Elisabet (toim.). 2011. Methods and Strategies of Process Research: Integrative Approaches in Translation Studies. Amsterdam: John Benjamins.

Ehrensberger-Dow, Maureen, Göpferich, Susanne \& O'Brien, Sharon (toim.). 2015. Interdisciplinarity in Translation and Interpreting Process Research. Amsterdam: John Benjamins.

Muñoz Martín, Ricardo (toim.). 2014. Minding Translation. MonTI, Special Issue 1. Saatavissa: http://rua.ua.es/dspace/handle/10045/43719.

Muñoz Martín, Ricardo (toim.). 2016. Reembedding Translation Process Research. Amsterdam: John Benjamins.

O'Brien, Sharon (toim.). 2011. Cognitive Explorations of Translation. London: Continuum.

Shreve, Gregory M. \& Angelone, Erik (toim.). 2010. Translation and Cognition. Amsterdam: John Benjamins.

\subsection{Toimijoiden, toimintaympäristön ja vastaanoton tutkimus}

Toimijoiden ja toimintaympäristön tutkimuksessa tavanomainen lähestymistapa on etnografinen, sillä etnografia pyrkii kuvaamaan yksityiskohtaisesti kulttuuria, yhteisöä tai ryhmää, sen instituutioita, uskomuksia, tuotteita ja käyttäytymistä sosiaalisessa kontekstissaan (ks. esim. Fetterman 20II). Ryhmän toimintaa ei tarkastella vain tutkijan näkökulmasta, vaan olennaista on yhteisöön kuuluvien näkökulma. Etnografinen tutkimusote on tullut yhä suositummaksi käännöstieteessä 2000-luvulla, kun tutkijat ovat kiinnostuneet kääntämisestä ja tulkkaamisesta sosiaalisena ja tilanteisena toimintana, kääntämisen ja tulkkauksen käytänteistä ja prosesseista, toimintaympäristöistä, toimijoista sekä kääntäjän tai tulkin roolista käännös- ja tulkkausviestinnässä. 
Etnografian ydintä ovat kenttätutkimus ja yhteisön toiminnan havainnointi sen luonnollisessa ympäristössä, mutta aineisto ja sen keruun ja analyysin menetelmät ovat moninaiset, ja tyypillisesti tutkimuksessa yhdistetään monenlaisia aineistoja ja useampia menetelmiä (ks. Lingvistinen etnografia toimintayhteisöissä tk.).

Sekä haastattelujen että kyselyjen avulla on selvitetty kääntäjien ja tulkkien näkemyksiä heidän ammatillisesta statuksestaan ja identiteetistään sekä roolistaan. Esimerkiksi Katan (2009) teki maailmanlaajuisen internetkyselyn, jossa selvitettiin vastaajien näkemyksiä kääntäjän ja tulkin roolista, ammatin statuksesta, ammatillisesta tyytyväisyydestä ja koulutuksesta. Kyselyyn vastasi noin I ০o० kääntäjää ja tulkkia sekä kääntämisen opettajaa ja opiskelijaa. Damin ja Zethsenin kyselytutkimukset (esim. 20I2) eri tehtävissä toimivien tanskalaisten kääntäjien statuksesta ovat olleet esimerkkeinä myös suomalaisille vastaaville tutkimuksille (esim. Ruokonen 20ı6).

Etnografinen tutkimus on tyypillisesti monimenetelmäistä, ja se pyrkii antamaan kohteestaan monipuolisen ja rikkaan kuvauksen. Antropologian käsite tiheä kuvaus (engl. thick description) on siirretty käännöstieteeseen käsitteellä thick translation (Appiah I993). Tyypillisesti tällainen etnografinen tutkimus yhdistää havainnointia, haastattelua tai kyselyä sekä tekstien tai dokumenttien analyysia. Varhaisimpia laajoja etnografisia tutkimuksia on Susan Berk-Seligsonin (I990) tutkimus espanja-englanti-oikeustulkkauksesta Yhdysvalloissa. Hän havainnoi oikeussalissa tulkkausta päivittäin seitsemän kuukauden ajan, nauhoitti tulkkauksia yhteensä II4 tuntia ja analysoi nauhoitukset. Lisäksi hän haastatteli sekä tulkkeja että viranomaisia. Kaisa Koskisen (2008) etnografinen tutkimus tarkasteli EU:n komission kääntämistä. Hän tutki institutionaalista kontekstia ja kääntäjiä, jotka toimivat tässä kontekstissa, sekä käännettyjä dokumentteja ja niiden lähdetekstejä. Menetelminä olivat fokusryhmähaastattelu, kysely, (osallistuva) havainnointi ja tekstien analyysi (käännössiirtymien analyysi ja kriittinen diskurssianalyysi). Koskisen tutkimus on myös esimerkki käännöstieteellisestä tapaustutkimuksesta; tapaus on rajattu Euroopan komission Suomen Luxemburgissa sijaitsevaan käännösyksikköön. Tapaustutkimus on niin ikään Hokkasen (20I6) autoetnografinen tutkimus, jossa hän havainnoi 
tulkkausta helluntaiseurakunnassa, piti kirjaa omista tulkkauskokemuksistaan ja nauhoitti omia tulkkauksiaan.

Kuten edelliset esimerkit osoittavat, etnografisissa tutkimuksissa yhdistyvät usein tuotteen, prosessin, toimijoiden, toimintaympäristön ja vastaanoton tutkimukset, jotka tässä artikkelissa olemme selvyyden vuoksi osin erottaneet omiksi luvuikseen. Esimerkiksi Ebru Dirikerin (2004) tutkimuksessa konferenssitulkkauksesta aineistona oli nauhoitettuja tulkkauksia, tulkkauksesta käytyä julkista keskustelua sekä konferenssitulkkien, järjestäjien, puhujien ja osallistujien haastatteluja. Kuten Dirikerin tutkimuksessa käännöstieteellinen tutkimus on kääntäjien ja tulkkien lisäksi kiinnostunut myös muista kääntämisen ja tulkkauksen kentän toimijoista.

Etnografisessa tutkimuksessa käytetään myös bibliografisia aineistoja ja arkistodokumentteja; kiinnostuksen kohteena voi olla esimerkiksi tietyn aikakauden käännös- ja tulkkaustoiminta (Kujamäki \& Paloposki 20I5). Historiallinen tutkimus voi kohdistua myös yhteen henkilöön, esimerkkinä Paloposken tutkimus Samuli Suomalaisesta (I850-I907) kääntäjänä (Paloposki 2OI7).

Kenttätutkimuksesta uudenlaisia esimerkkejä ovat translationaalisen tilan tutkimus eli monikielisen tilan tarkasteleminen kääntämisen paikkana (Koskinen 20I3a), kuten Tampereen kielimaiseman tutkimus "käännettyyden" näkökulmasta (Koskinen 2013b) ja Helsinki-Pietariväliä pendelöivän Allegro-junan monikielisen viestinnän tutkimus (Probirskaja 20I7). Molemmissa tutkimuksissa havainnointi on keskeinen aineiston keruun menetelmä, edellisessä aineistona on lisäksi valokuvia, jälkimmäisessä ohjeita ja haastatteluja.

Kääntämisen ja tulkkauksen vastaanoton tutkimuksessa tarkastellaan käännöksen tai tulkkauksen käytettävyyttä, hyväksyttävyyttä ja ymmärrettävyyttä, yleisesti ottaen laatua. Laatu on riippuvainen kääntämisen tai tulkkauksen tarkoituksesta ja vastaanottajan tarpeista. Esimerkiksi konferenssitulkkauksen osanottajilla, oikeusprosessin viranomaisilla ja lääkärin vastaanoton potilaalla voi olla hyvin erilaisia odotuksia tulkkaukselle, minkä vuoksi tulkkauksen laadulle on vaikea määritellä yleisiä kriteereitä. Odotukset voivat vaihdella myös sen mukaan, mitä kussakin kulttuurissa minäkin aikana pidetään hyvänä tulkkauksena. 
Esimerkiksi monessa maassa juristit odottavat oikeustulkkaukselta sanasanaista tulkkausta (Kalina 20I6), mutta Kadricin (200I) kyselytutkimuksen mukaan Itävallassa tuomarit pitävät tärkeämpänä tyylin ja rekisterin uskollisuutta. Konferenssitulkkausta koskevissa kyselytutkimuksissa (esim. Vuorikoski I996) on yleisesti todettu, että keskeisiä laatutekijöitä ovat uskollisuus alkuperäiselle puheelle, sisältö, synkronia, retoriset taidot ja äänenlaatu. Tärkeitä ovat niin ikään täydellisyys, ilmauksen selkeys ja terminologian tarkkuus. Toisaalta on myös havaittu, että odotukset vaihtelevat muun muassa kokoustyypin ja osallistujien simultaanitulkkauskokemuksen mukaan. (Pöchhacker 2004, I54.) Vastaavia kyselytutkimuksia on tehty myös esimerkiksi asiatekstien käännösten tilaajille (esim. Havumetsä 20I2).

Vastaanoton tutkimuksessa voidaan käyttää autenttisten käännösten ja tulkkausten lisäksi koeasetelmia, joissa tutkitaan, miten käännöksen tai tulkkauksen eri tekijät vaikuttavat vastaanottoon. Esimerkiksi Hale, Martschuk, Ozolins ja Stern (20I7) ovat tutkineet simuloitujen oikeustulkkausten avulla sitä, miten tulkkauslaji (konsekutiivi vs. simultaani) vaikuttaa lautamiesten arviointiin todistajan uskottavuudesta.

Uusista menetelmistä silmänliiketutkimus soveltuu myös tekstin luettavuuden ja ymmärrettävyyden tutkimukseen; esimerkiksi O’Brien (2010) on tutkinut konekäännetyn tekstin luettavuutta. TaivalkoskiShilov ja Koponen (20I7) ovat yhdistäneet silmänliiketutkimusta, haastatteluja ja osallistujien narratiivisia raportteja tutkiessaan, miten paratekstit ja lukijoiden akateeminen tausta vaikuttavat tieteellisen tekstin vastaanottoon. Silmänliiketutkimusta on käytetty lisäksi erityisesti tekstityksen vastaanottotutkimuksissa, joissa on selvitetty muun muassa tekstin määrän ja muodon (tiivistetty vs. puhetta tarkkaan noudattava) vaikutusta ymmärrettävyyteen ja elokuvan katsomiseen (esim. Szarkowska, Krejtz, Klyszejko \& Wieczorek 20II). Lång, Mäkisalo, Gowases ja Pietinen (2013) selvittivät silmänliiketutkimuksen avulla sitä, miten ruututekstityksen konventioiden noudattaminen vaikuttaa vastaanottoon. Silmänliiketutkimukseen yhdistetään usein kysely, jolla testataan tekstitetyn ohjelman ymmärtämistä.

Tekstityksen vastaanottoa on tutkittu myös fokusryhmien avulla, jolloin kohderyhmään kuuluvat vastaanottajat voivat keskustella 
tekstityksestä sekä katsoessaan tekstitettyä elokuvaa että välittömästi katsomisen jälkeen (esim. Tuominen 20I2; Tiittula 20I6). Fokusryhmätutkimuksen etuna esimerkiksi kyselyihin verrattuna on se, että yleisten näkemysten lisäksi saadaan konkreettisiin esiintymiin kommentteja sekä argumentointia eri ratkaisujen puolesta ja niitä vastaan. Usein vastaanottotutkimuksissakin yhdistetään monia menetelmiä, kuten Orrego-Carmona (20I6) teki tutkiessaan, erottavatko katsojat ammattitekstittäjän tekstityksen harrastajatekstittäjän tuotoksesta. Tutkimuksessa katsojille näytettiin eri tavoin tekstitettyjä elokuvakatkelmia ja vastaanottajien reaktioita tutkittiin silmänliikkeiden, kyselyn ja haastattelun avulla. Käännetyn kirjallisuuden vastaanoton tutkimuksessa voidaan käyttää edellä mainittujen menetelmien lisäksi arvosteluja, julkisia keskusteluja, lukijapalautteita sekä tilastoja.

\section{Toimijoiden ja toimintaympäristön tutkimusta:}

Angelelli, Claudia (toim.). 2014. The Sociological Turn in Translation and Interpreting Studies. Amsterdam: John Benjamins.

Biagin, Marta, Boyd, Michael S. \& Monacelli, Claudia (toim.). 2017. The Changing Role of the Interpreter. Contextualising Norms, Ethics and Quality Standards. New York (NY): Routledge.

Dam, Helle V. \& Zethsen, Karen Korning (toim.). 2009. Translation studies: Focus on the translator. Hermes, Special issue 42. Saatavissa: https://tidsskrift.dk/her/issue/view/2853.

Kinnunen, Tuija \& Koskinen, Kaisa (toim.). 2010. Translators' Agency. Tampere Studies in Language, Translation and Culture. Series B 4. [verkkoaineisto]. Tampere: Tampere University Press. Saatavissa: http:// urn.fi/urn:isbn:978-951-44-8082-9.

Sela-Sheffy, Rakefet \& Shlesinger, Miriam (toim.). 2011. Identity and Status in the Translational Professions. Amsterdam: John Benjamins.

Taivalkoski-Shilov, Kristiina, Tiittula, Liisa \& Koponen, Maarit (toim.). 2017. Communities in Translation and Interpreting. Vita traductiva 9. Montréal: Éditions québécoises de l'œuvre. 


\section{Kääntämisen historian tutkimuksen menetelmistä:}

Pym, Anthony. 1998. Method in Translation History. Manchester: St. Jerome.

Käännöstieteellisistä vastaanottotutkimuksista ja niissä käytetyistä menetelmistä:

Suojanen, Tytti, Koskinen, Kaisa \& Tuominen, Tiina. 2012. Käyttäjäkeskeinen kääntäminen. [verkkoaineisto]. Tampere: Tampereen yliopisto. Saatavissa: http://urn.fi/URN:ISBN:978-951-44-8839-9.

\section{Yhteenveto}

Katsaus käännöstieteen historiaan, tutkimusaineistoihin, -menetelmiin ja -kysymyksiin nostaa esille tieteenalan itsenäistymisen emotieteenaloista. Temaattisesti kehitys on kulkenut produktin, kirjoitettujen käännösten ja puhuttujen tulkkeiden tutkimuksesta multimodaalisiin tuotoksiin ja vuorovaikutustilanteisiin sekä toimintaprosessien, toimijoiden, toimintaympäristöjen ja vastaanoton kysymysten tutkimukseen. Menetelmällisesti kehitys on yhtäältä säilyttänyt perinteisiä tekstianalyysin manuaalisia menetelmiä mutta tuonut toisaalta mukanaan siirtymän tallennuksessa, mittauksessa ja analyysissa tietokoneohjelmiin sekä sähköisiin mittaus- ja tallennusvälineisiin. Mukaan on tullut myös toimintakentän, toimijoiden ja vastaanottajien etnografinen tutkimus. Yhä useammin tutkimus on moniaineistoista ja monimenetelmäistä. Menetelmien ja välineiden kehittyessä on kiinnitetty myös enemmän huomiota tutkimuskysymyksiin, jotka nousevat yhteiskunnasta. Kääntämisen ja tulkkauksen ilmiöt ovat jatkuvan muutoksen alaisia. Yhteiskunnallisten ja teknologisten muutosten myötä syntyy uusia kääntämisen ja tulkkauksen alueita ja muotoja, joita on vaikea sijoittaa vanhoihin kategorioihin. Tällainen on esimerkiksi reaaliaikainen tekstitys. Käännös- ja kieliteknologia, ihmisen ja koneen 
välinen vuorovaikutus sekä yhä monikielisempi yhteiskunta ja saavutettavuuden haasteet asettavat uusia tehtäviä käännöstieteelliselle tutkimukselle. Samalla vaatimus tieteidenvälisyydestä on kasvanut, vaikka käännöstiede onkin aina ollut pohjimmiltaan monitieteistä.

\section{Aiheesta lisää:}

\section{Käännöstieteellisen tutkimuksen ajankohtaisia käsikirjoja:}

Gambier, Yves \& Doorslaer, Luc van (toim.). 2010-2016. Handbook of Translation Studies Online. [verkkoaineisto]. Amsterdam: John Benjamins.

Malmkjær, Kirsten \& Windle, Kevin (toim.). 2011. Oxford Handbook of Translation Studies. Oxford: Oxford University Press.

Millán, Carmen \& Bartrina, Francesca (toim.). 2013. Routledge Handbook of Translation Studies. London: Routledge.

Pöchhacker, Franz (toim.). 2015. Routledge Encyclopedia of Interpreting Studies. New York (NY): Routledge.

Käännöstieteellisen tutkimuksen ajankohtaisia metodioppaita:

Angelelli, Claudia \& Baer, Brian James (toim.). 2015. Researching Translation and Interpreting. New York (NY): Routledge.

Bogucki, Łukasz. 2016. Areas and Methods of Audiovisual Translation Research. (2. uud. laitos). Frankfurt am Main: Peter Lang Edition.

Hale, Sandra \& Napier, Jemina. 2013. Research Methods in Interpreting: A Practical Resource. New York (NY): Continuum.

Olohan, Maeve (toim.). 2000. Intercultural Faultlines. Research Modals in Translation Studies I. Textual and Cognitive Aspects. Manchester: St. Jerome.

Saldanha, Gabriela \& O'Brien, Sharon. 2013. Research Methodologies in Translation Studies. London: Routledge. 


\section{Muita hyödyllisiä lähteitä:}

Gambier, Yves \& Doorslaer, Luc van (toim.). 2004-. Translation Studies Bibliography. [verkkoaineisto]. Amsterdam: John Benjamins.

\section{VIITTEET}

1 http://www.hf.uio.no/ilos/english/services/omc/enpc/.

2 https://www.alc.manchester.ac.uk/translation-and-intercultural-studies/research/ projects/translational-english-corpus-tec/.

3 http://metashare.csc.fi/repository/browse/the-finnish-broadcasting-company-corpus-of-subtitles/6c23ccd8fccc11e18b49005056be118ed 4 f163dbb7344fc3bcc4969c9500721e/.

4 http://opus.lingfil.uu.se/.

5 Katsauksen kääntämisen universaalien tutkimukseen luo esimerkiksi Mauranen (2006).

6 http://metashare.elda.org/repository/browse/european-parliament-interpretationcorpus-epic/fde33884de7611e2b1e400259011f6ea48ac8ceob41f48e6be224bbee$9 \mathrm{~d} 5 \mathrm{gcb} / \mathrm{s}$.

7 http://www.yorku.ca/comindat/comindat.htm.

\section{KIRJALLISUUS}

Abdallah, Kristiina. 2012. Translators in Production Networks. Reflections on Agency, Quality and Ethics. Publications of the University of Eastern Finland. Dissertations in Education, Humanities, and Theology 21. Joensuu: Itä-Suomen yliopisto. [verkkoaineisto]. [viitattu 23.12.2017]. Saatavissa: http://urn.fi/URN:ISBN:978-952-61-0609-0.

Angermeyer, Philipp Sebastian, Meyer, Bernd \& Schmidt, Thomas. 2012. Sharing community interpreting corpora: a pilot study. Julkaisussa: Schmidt, Thomas \& Wörner, Kai (toim.) Multilingual Corpora and Multilingual Corpus Analysis. Amsterdam: John Benjamins, 275-294.

Appiah, Kwame Anthony. 1993. Thick translation. Callaloo 16:4, 808-819.

Baker, Mona. 1993. Corpus linguistics and translation studies. Implications and applications. Julkaisussa: Baker, Mona, Francis, Gill \& Tognini Bonelli, Elena (toim.) Text and Technology. In Honour of John Sinclair. Amsterdam: John Benjamins, 233-250.

Baker, Mona. 1996. Corpus-based translation studies: The challenges that lie ahead. Julkaisussa: Somers, Harold (toim.) Terminology, LSP and Translation. Studies in Language Engineering in Honour of Juan C. Sager. Amsterdam: John Benjamins, 175-186.

Becher, Viktor. 2011. Explicitation and Implicitation in Translation. A Corpus-based Study of English-German and German-English Translations of Business Texts. Väitöskirja. Hampuri: 
Hampurin yliopisto. [verkkoaineisto]. [viitattu 14.1.2018]. Saatavissa: https://d-nb. info/102042673X/34.

Bendazzoli, Claudio. 2015. Corpus-based research. Julkaisussa: Pöchhacker, Franz (toim.) Routledge Encyclopedia of Interpreting Studies. Florence: Taylor \& Francis, 132-135.

Bendazzoli, Claudio. 2018. Corpus-based interpreting studies: past, present and future developments of a (wired) cottage industry. Julkaisussa: Russo, Mariachiara, Bendazzoli, Claudio \& Defrancq, Bart (toim.) Making Way in Corpus-based Interpreting Studies. New York (NY): Springer, 1-20.

Berk-Seligson, Susan. 1990. The Bilingual Courtroom: Court Interpreters in the Judicial Process. Chicago (IL): The University of Chicago Press.

Bernardini, Silvia, Ferraresi, Adriano, Russo, Mariachiara, Collard, Camille \& Defrancq, Bart. 2018. Building interpreting and intermodal corpora: A how-to for a formidable task. Julkaisussa: Russo, Mariachiara, Bendazzoli, Claudio \& Defrancq, Bart (toim.) Making Way in Corpus-based Interpreting Studies. New York (NY): Springer, 21-42.

Braun, Sabine \& Taylor, Judith L. 2011. AVIDICUS comparative studies - part I: Traditional interpreting and remote interpreting in police interviews. Julkaisussa: Braun, Sabine \& Taylor, Judith L. (toim.) Videoconference and Remote Interpreting in Criminal Proceedings. Guildford: University of Surrey, 85-100.

Bundgaard, Kristine, Paulsen Christensen, Tina \& Schjoldager, Anne. 2016. Translatorcomputer interaction in action - an observational process study of computer-aided translation. The Journal of Specialised Translation 25, 106-130. [verkkoaineisto]. [viitattu 29.12.2017]. Saatavissa: http://www.jostrans.org/issue25/art_bundgaard.pdf.

Cappelle, Bert \& Loock, Rudy. 2017. Typological differences shining through. The case of phrasal verbs in translated English. Julkaisussa: Delaere, Isabelle, Lefer, Marie-Aude \& De Sutter, Gert (toim.) Empirical Translation Studies: New Methodological and Theoretical Traditions. Berlin: De Gruyter Mouton, 235-264.

Castagnoli, Sara, Ciobanu, Dragoş, Kunz, Kerstin, Kübler, Natalie \& Volanschi, Alexandra. 2011. Designing a translator learner corpus for training purposes. Julkaisussa: Kübler, Natalie (toim.) Corpora, Language, Teaching and Resources: from Theory to Practice. Bern: Lang, 221-248. [verkkoaineisto]. [viitattu 17.10.2017]. Saatavissa: http://www.eila.univparis-diderot.fr/_media/user/alexandra_volanschi/publi/castagnoli_et_al.pdf.

Catford, John Cunnison. 1965. A Linguistic Theory of Translation: An Essay in Applied Linguistics. London: Oxford University Press.

Chesterman, Andrew. 2004. Beyond the particular. Julkaisussa: Mauranen, Anna \&

Kujamäki, Pekka (toim.) Translation Universals: Do they Exist? Amsterdam: John

Benjamins, 33-49.

Chesterman, Andrew. 2016 [1997]. Memes of Translation: The Spread of Ideas in Translation Theory. Amsterdam: John Benjamins.

Dam, Helle V. \& Zethsen, Karen Korning. 2012. Translators in international organizations. A special breed of high-status professionals? Danish EU translators as a case in point. Translation and Interpreting Studies 7:2, 211-232.

Delaere, Isabelle \& De Sutter, Gert. 2017. Variability of English loanword use in Belgian Dutch translations. Measuring the effect of source language and register. Julkaisussa: Delaere, Isabelle, Lefer, Marie-Aude \& De Sutter, Gert (toim.) Empirical Translation 
Studies: New Methodological and Theoretical Traditions. Berlin: De Gruyter Mouton, 81-112. Delaere, Isabelle, Lefer, Marie-Aude \& De Sutter, Gert (toim.). 2017. Empirical Translation Studies: New Methodological and Theoretical Traditions. Berlin: De Gruyter Mouton.

Diriker, Ebru. 2004. De-/re-contextualizing Conference Interpreting: Interpreters in the Ivory Tower? Amsterdam: John Benjamins.

Dragsted, Barbara. 2010. Coordination of reading and writing processes in translation: an eye on uncharted territory. Julkaisussa: Shreve, Gregory M. \& Angelone, Erik (toim.) Translation and Cognition. Amsterdam: John Benjamins, 41-62.

Englund Dimitrova, Birgitta. 2005. Expertise and Explicitation in the Translation Process. Amsterdam: John Benjamins.

Englund Dimitrova, Birgitta. 2016. Translation process. Julkaisussa: Gambier, Yves \& Doorslaer, Luc van (toim.) 2010-2016. Handbook of Translation Studies Online. Amsterdam: John Benjamins. [verkkoaineisto]. [viitattu 30.12.2017]. Saatavissa: DOI: 10.1075/hts.1.tra6.

Englund Dimitrova, Birgitta \& Hyltenstam, Kenneth (toim.). 2000. Language Processing and Simultaneous Interpreting: Interdisciplinary Perspectives. Amsterdam: John Benjamins.

Even-Zohar, Itamar. 1990. Polysystem Studies. Durham: Duke University Press. Special issue of Poetics Today 11:1.

Evert, Stefan \& Neumann, Stella. 2017. The impact of translation direction on characteristics of translated texts. A multivariate analysis for English and German. Julkaisussa: Delaere, Isabelle, Lefer, Marie-Aude \& De Sutter, Gert (toim.) Empirical Translation Studies: New Methodological and Theoretical Traditions. Berlin: De Gruyter Mouton, 47-80.

Fetterman, David M. 2011. Ethnography. Julkaisussa: Lewis-Beck, Michael S., Bryman, Alan \& Liao, Tim Futing (toim.) The SAGE Encyclopedia of Social Science Research Methods. Thousand Oaks (CA): Sage, 329-332.

Gavioli, Laura \& Baraldi, Claudio. 2011. Interpreter-mediated interaction in healthcare and legal settings: talk organization, context and the achievement of intercultural communication. Interpreting 13:2, 205-233.

Gile, Daniel. 1997. Conference interpreting as a cognitive management problem. Julkaisussa: Danks, Joseph H., Shreve, Gregory M., Fountain, Stephen B., \& McBeath, Michael K. (toim.) Cognitive Processes in Translation and Interpreting. Thousand Oaks (CA): Sage, 196-214.

Gile, Daniel. 2009. Interpreting studies: A critical view from within. MonTI: Monografías de traducción e interpretación 1, 135-155.

Gile, Daniel. 2015. Experimental research. Julkaisussa: Angelelli, Claudia \& Baer, Brian James (toim.) Researching Translation and Interpreting. New York (NY): Routledge, 220228.

Göpferich, Susanne, Bayer-Hohenwarter, Gerrit, Prassl, Friederike \& Stadlober, Johanna. 2011. Exploring translation competence acquisition: criteria of analysis put to the test. Julkaisussa: O'Brien, Sharon (toim.) Cognitive Explorations of Translation. London: Continuum, 57-85.

Hale, Sandra, Martschuk, Natalie, Ozolins, Uldis \& Stern, Ludmila. 2017. The effect of interpreting modes on witness credibility assessments. Interpreting 19:1, 69-96. 
Hale, Sandra \& Napier, Jemina 2013. Research Methods in Interpreting: A Practical Resource. New York (NY): Continuum.

Hansen, Gyde. 2006. Retrospection methods in translator training and translation research. The Journal of Specialised Translation 5, 2-41. [verkkoaineisto]. [viitattu 29.12.2017]. Saatavissa: http://www.jostrans.org/issueo5/art_hansen.php.

Harjunpää, Katariina. 2017. Translatory Practices in Everyday Conversation. Bilingual Mediating in Finnish-Portuguese Interaction. Helsinki: Helsingin yliopisto. [verkkoaineisto]. [viitattu 21.8.2017]. Saatavissa: http://urn.fi/URN:ISBN: 978-957-51-3227-7.

Havumetsä, Nina. 2012. The Client Factor: A Study of Clients' Expectations Regarding Non-literary Translators and the Quality of Non-literary Translations. Helsinki: Helsingin yliopisto. [verkkoaineisto]. [viitattu 19.12.2017]. Saatavissa: http://urn.fi/ URN:ISBN:978-952-10-8392-1.

Hirvonen, Maija \& Tiittula, Liisa. 2018. How are translations created? Using multimodal conversation analysis to study a team translation process. Linguistica Antverpiensia, New Series: Themes in Translation Studies 17, 157-173. [verkkoaineisto]. [viitattu 24.2.2019]. Saatavissa: https://lans-tts.uantwerpen.be/index.php/LANS-TTS/issue/view/19. Hokkanen, Sari. 2016. To Serve and to Experience: An Autoethnographic Study of Simultaneous Church Interpreting. Tampere: Tampereen yliopisto. [verkkoaineisto]. [viitattu 19.12.2017]. Saatavissa: http://urn.fi/URN:ISBN:978-952-03-0232-O.

Holmes, James S. 2000 [1972]. The name and nature of translation studies. Julkaisussa:

Venuti, Lawrence (toim.) The Translation Studies Reader. London: Routledge, 172-191.

Holz-Mänttäri, Justa. 1984. Translatorisches Handeln: Theorie und Methode. Helsinki: Suomalainen Tiedeakatemia.

Isolahti, Nina. 2014. Tulkkauksen tarkkuus rikosoikeudenkäynnissä - saavuttamaton ihanne.

Acta Electronica Universitatis Tamperensis 1374. Tampere: Tampereen yliopisto.

[verkkoaineisto]. [viitattu 23.12.2017]. Saatavissa: https://tampub.uta.fi/bitstream/ handle/10024/94867/978-951-44-9329-4.pdf? sequence=1.

Jakobsen, Arnt Lykke. 2003. Effects of think aloud on translation speed, revision and segmentation. Julkaisussa: Alves, Fabio (toim.) Triangulating Translation. Perspectives in Process Oriented Research. Amsterdam: John Benjamins, 69-95.

Jakobsen, Arnt Lykke \& Jensen, Kristian T. H. 2008. Eye movement behaviour across four different types of reading task. Julkaisussa: Mees, Inger M., Jacobsen, Arnt Lykke \& Göpferich, Susanne (toim.) Looking at Eyes: Eye-tracking Studies of Reading and Translation Processing. Frederiksberg: Samfundslitteratur Press, 103-124.

Jakobson, Roman. 2000 [1959]. On linguistic aspects of translation. Julkaisussa: Venuti, Lawrence (toim.) The Translation Studies Reader. London: Routledge, 113-118.

Jiménez-Crespo, Miguel A. 2016. Translation crowdsourcing: research trends and perspectives. Julkaisussa: Cordingley, Anthony \& Frigau Manning, Céline (toim.) Collaborative Translation: From the Renaissance to the Digital Age. London: Bloomsbury, 192-211.

Johansson, Stig. 2007. Seeing through Multilingual Corpora: On the Use of Corpora in Contrastive Studies. Amsterdam: John Benjamins. 
Jääskeläinen, Riitta. 1999. Tapping the Process: An Explorative Study of the Cognitive and Affective Factors Involved in Translating. Väitöskirja. Joensuu: Joensuun yliopisto.

Jääskeläinen, Riitta. 2011b. Back to basics: designing a study to determine the validity and reliability of verbal report data on translation process. Julkaisussa: O'Brien, Sharon (toim.) Cognitive Explorations of Translation. London: Continuum, 15-29.

Kadric, Mira. 2001. Dolmetschen bei Gericht: Erwartungen, Anforderungen, Kompetenzen. Wien: WUV Universitätsverlag.

Kalina, Sylvia. 2016. Quality in interpreting. Julkaisussa: Gambier, Yves \& Doorslaer, Luc van (toim.) Handbook of Translation Studies Online. Amsterdam: John Benjamins. [verkkoaineisto]. [viitattu 18.12.2017]. Saatavissa: DOI: 10.1075/hts.3.qua2.

Katan, David. 2009. Occupation or profession: a survey of the translators' world. Translation and Interpreting Studies 4:2, 187-209.

Kemppanen, Hannu. 2008. Avainsanoja ja ideologiaa: käännettyjen ja ei-käännettyjen historiatekstien korpuslingvistinen analyysi. Väitöskirja. Joensuu: Joensuun yliopisto.

Kemppanen, Hannu. 2011. Pamphlet or scholarly work. Book reviews and determining the place of a translation. Julkaisussa: Kujamäki, Pekka, Kolehmainen, Leena, Penttilä, Esa \& Kemppanen, Hannu (toim.) Beyond Borders - Translations Moving Languages, Literatures and Cultures. Berlin: Frank \& Timme, 145-162.

Kinnunen, Tuija. 2010. Agency, activity and court interpreting. Julkaisussa: Kinnunen, Tuija \& Koskinen, Kaisa (toim.) Translators' Agency. Tampere Studies in Language, Translation and Culture. Series B 4. Tampere: Tampere University Press, 126-164. [verkkoaineisto]. [viitattu 23.12.2017]. Saatavissa: http://urn.fi/urn:isbn:978-951-44-8082-9.

Kinnunen, Tuija. 2013. Oikeusturva, oikeustulkkaus ja translationaali tila. Julkaisussa: Koskinen, Kaisa (toim.) Tulkattu Tampere. Tampere: Tampere University Press, 71-105. Kinnunen, Tuija \& Koskinen, Kaisa (toim.). 2010. Translators' Agency. Tampere Studies in Language, Translation and Culture. Series B 4. Tampere: Tampere University Press. [verkkoaineisto]. [viitattu 23.12.2017]. Saatavissa: http://urn.fi/urn:isbn:978-957-44-8082-9. Koglin, Arlene. 2015. An empirical investigation of cognitive effort required to post-edit machine translated metaphors compared to the translation of metaphors. Translation $Q$ Interpreting 7:1, 126-141.

Kolehmainen, Leena, Miestamo, Matti \& Nordlund, Taru (toim.). 2013. Kielten vertailun metodiikka. Suomalaisen Kirjallisuuden Seuran Toimituksia 1387. Helsinki: Suomalaisen Kirjallisuuden Seura.

Koller, Werner. 1979. Einführung in die Übersetzungswissenschaft. Heidelberg: Quelle \& Meyer.

Koskela, Merja, Koskinen, Kaisa \& Pilke, Nina. 2017. Bilingual formal meeting as a context of translatoriality. Target 29:3, 464-485.

Koskinen, Kaisa. 2008. Translating Institutions: An Ethnographic Study of EU Translation. Manchester: St. Jerome.

Koskinen, Kaisa (toim.). 2013a. Tulkattu Tampere. Tampere: Tampere University Press. Koskinen, Kaisa. 2013b. Turistina Hervannan kielimaisemassa: käännettyyden jäljillä. Julkaisussa: Koskinen, Kaisa (toim.) Tulkattu Tampere. Tampere: Tampere University Press, 313-334. 
Koskinen, Kaisa \& Paloposki, Outi. 2015. Sata kirjaa, tuhat suomennosta: kaunokirjallisuuden uudelleenkääntäminen. Suomalaisen Kirjallisuuden Seuran Toimituksia 1410. Helsinki: Suomalaisen Kirjallisuuden Seura.

Kruger, Haidee. 2017. The effects of editorial intervention. Implications for studies of the features of translated language. Julkaisussa: Delaere, Isabelle, Lefer, Marie-Aude \& De Sutter, Gert (toim.) Empirical Translation Studies: New Methodological and Theoretical Traditions. Berlin: De Gruyter Mouton, 113-156.

Kruger, Jan-Louis. 2012. Making meaning in AVT: Eye tracking and viewer construction of narrative. Perspectives: Studies in Translatology 20:1, 67-86.

Kujamäki, Pekka. 1998. Deutsche Stimmen der Sieben Brüder. Ideologie, Poetik und Funktionen literarischer Übersetzung. Frankfurt a.M.: Peter Lang.

Kujamäki, Pekka \& Paloposki, Outi. 2015. Sujuvasti suomesta saksaan kääntävä konekirjoittajatar saa paikan heti: historian näkökulma kääntäjyyteen ammattina tai tehtävänä. Virittäjä 119:3, 342-371.

Kumpulainen, Minna. 2016. Learning Translation: An Empirical Study into the Acquisition of Interlingual Text Production Skills. Publications of the University of Eastern Finland. Dissertations in Education, Humanities, and Theology, no 91. Joensuu: Itä-Suomen yliopisto. [verkkoaineisto]. [viitattu 15.12.2017]. Saatavissa: http://urn.fi/ URN:ISBN:978-952-61-2235-9.

Kussmaul, Paul. 1995. Training the Translator. Philadelphia: John Benjamins.

Kuusi, Päivi. 2011. Miksi näkökulma muuttuu käännöksessä? Eksplisiittistämisen ja normaalistamisen selitysvoima ja seuraukset. Väitöskirja. Tampere: Tampereen yliopisto. [verkkoaineisto]. [viitattu 23.12.2017]. Saatavissa: http://tampub.uta.fi/bitstream/ handle/10024/66777/978-951-44-8522-0.pdf? sequence=1\&isAllowed=y.

Kuusi, Päivi. 2016. Features of discourse presentation in translation: Literary and narratological insights into translation universals. International Journal of Literary Linguistics 5:3, 1-24.

Laviosa, Sara. 1996. The English Comparable Corpus (ECC): A Resource and Methodology for the Empirical Study of Translation. Manchester: University of Manchester.

Laviosa, Sara, Pagano, Adriana, Kemppanen, Hannu \& Ji, Meng. 2017. Textual and Contextual Analysis in Empirical Translation Studies. Singapore: Springer.

Lång, Juha, Mäkisalo, Jukka, Gowases, Tersia \& Pietinen, Sami. 2013. Using eye tracking to study the effect of badly synchronized subtitles on the gaze paths of television viewers. New Voices in Translation Studies 10, 72-86. [verkkoaineisto]. [viitattu 29.12.2017]. Saatavissa: https://www.iatis.org/index.php/new-voices-in-translation-studies/item/794issue10-2013.

Mason, Ian. 2012. Gaze, positioning and identity in interpreter-mediated dialogues. Julkaisussa: Baraldi, Claudio \& Gavioli, Laura (toim.) Coordinating Participation in Dialogue Interpreting. Amsterdam: John Benjamins, 177-200.

Mauranen, Anna. 2000. Strange strings in translated language. A study on corpora. Julkaisussa: Olohan, Maeve (toim.) Intercultural Faultlines. Research Models in Translation Studies I. Textual and Cognitive Aspects. Manchester: St. Jerome, 119-141. 
Mauranen, Anna. 2004. Corpora, universals and interference. Julkaisussa: Mauranen, Anna \& Kujamäki, Pekka (toim.) Translation Universals. Do They Exist? Amsterdam: John Benjamins, 65-82.

Mauranen, Anna. 2006. Translation universals. Julkaisussa: Brown, Keith, Anderson, Anne, Bauer, Laurie, Berns, Margie, Hirst, Graeme \& Miller, Jim (toim.) Encyclopedia of Language and Linguistics. Amsterdam: Elsevier, 93-100.

Monti, Cristina, Bendazzoli, Claudio, Sandrelli, Annalisa \& Russo, Mariachiara. 2005. Studying directionality in simultaneous interpreting through an electronic corpus: EPIC (European Parliament Interpreting Corpus). Meta 50:4. [verkkoaineisto]. [viitattu 17.10.2017]. Saatavissa: https://www.erudit.org/en/journals/meta/2005-v50-n4meta1024/019850ar.pdf.

Munday, Jeremy. 2012. Introducing Translation Studies: Theories and Applications. (3. p.). New York (NY): Routledge.

Munday, Jeremy. 2015. The role of archival and manuscript research in the investigation of translator decision-making. Julkaisussa: Ehrensberger-Dow, Maureen, Göpferich, Susanne \& O'Brien, Sharon (toim.) Interdisciplinarity in Translation and Interpreting Process Research. Amsterdam: John Benjamins, 127-140.

Muñoz Martín, Ricardo. 2010. On paradigms and cognitive translatology. Julkaisussa: Shreve, Gregory M. \& Angelone, Erik (toim.) Translation and Cognition. Amsterdam: John Benjamins, 169-187.

Nida, Eugene Albert. 1964. Toward a Science of Translating: With Special Reference to Principles and Procedures Involved in Bible Translating. Leiden: Brill.

O'Brien, Sharon. 2006. Pauses as indicators of cognitive effort in post-editing machine translation output. Across Languages and Cultures 7:1, 1-21.

O'Brien, Sharon. 2010. Controlled language and readability. Julkaisussa: Shreve, Gregory M. \& Angelone, Erik (toim.) Translation and Cognition. Amsterdam: John Benjamins, 143-165.

O'Brien, Sharon (toim.). 2011. Cognitive Explorations of Translation. London: Continuum.

Orrego-Carmona, David. 2016. A reception study on non-professional subtitling: do audiences notice any difference? Across Languages and Cultures 17:2, 163-181.

PACTE Group. 2011. Results of the validation of the PACTE translation competence model: translation project and dynamic translation index. Julkaisussa: O'Brien, Sharon (toim.) Cognitive Explorations of Translation. London: Continuum, 30-56.

Paloposki, Outi. 2007. Suomentaminen ja suomennokset 1800-luvulla. Julkaisussa: Riikonen, H. K., Kovala, Urpo, Kujamäki, Pekka \& Paloposki, Outi (toim.) Suomennoskirjallisuuden historia I. Suomalaisen Kirjallisuuden Seuran Toimituksia 1084. Helsinki: Suomalaisen Kirjallisuuden Seura, 102-126.

Paloposki, Outi. 2017. In search of an ordinary translator: translator histories, working practices and translator-publisher relations in the light of archival documents. The Translator 23:1, 31-48.

Pavlović, Tanja. 2013. The role of collaborative translation protocols (CTPs) in translation studies. Jezikoslovlje 14, 549-563. [verkkoaineisto]. [viitattu 15.12.2017]. Saatavissa: http:/l hrcak.srce.hr/file/165567. 
Pokorn, Nike K. 2005. Challenging the Traditional Axioms: Translation into a Non-mother Tongue. Amsterdam: John Benjamins.

Probirskaja, Svetlana. 2009. Rajankäyntiä. Suomen ja Venäjän kahdenväliset valtiosopimukset käännöstieteellisen avainsana-analyysin valossa. [verkkoaineisto]. [viitattu 23.12.2017].

Tampere: Tampereen yliopisto. Saatavissa: http://urn.fi/urn:isbn:978-951-44-7629-7.

Probirskaja, Svetlana. 2017. "Does anybody here speak Finnish?" Linguistic first aid and emerging translational spaces on the Finnish-Russian Allegro train. Translation Studies $10: 3,231-246$.

Prunč, Erich. 2007. Entwicklungslinien der Translationswissenschaft: Von den Asymmetrien der Sprachen zu den Asymmetrien der Macht. Berlin: Frank \& Timme.

Pym, Anthony. 2010. Exploring Translation Theories. New York (NY): Routledge.

Pöchhacker, Franz. 2004. Introducing Interpreting Studies. London: Routledge.

Pöchhacker, Franz (toim.). 2015. Routledge Encyclopedia of Interpreting Studies. New York (NY): Routledge.

Pöchhacker, Franz \& Kadric, Mira. 1999. The hospital cleaner as healthcare interpreter. A case study. The Translator 5:2, 161-178.

Reiß, Katharina \& Vermeer, Hans J. 1984. Grundlegung einer allgemeinen Translationstheorie. Tübingen: Niemeyer.

Risku, Hanna. 2012. Cognitive approaches to translation. Julkaisussa: Chapelle, Carol A. (toim.) The Encyclopedia of Applied Linguistics. [verkkoaineisto]. [viitattu 29.12.2017]. DOI: 10.1002/9781405198431.wbealo145.

Risku, Hanna. 2014. Translation process research as interaction research: From mental to socio-cognitive processes. MonTI: Monografías de traducción e interpretación 1, 331-353. [verkkoaineisto]. [viitattu 22.10.2017]. Saatavissa: http://www.e-revistes.uji.es/index.php/ monti/article/view/1711.

Risku, Hanna, Rogl, Regina \& Milosevic, Jelena. 2017. Translation practice in the field. Current research on socio-cognitive processes. Translation Spaces 6:1, 3-26.

Rouhe, Olga. 2017. Kieliopin rakenne-erojen vaikutus suomi-venäjä-simultaanitulkkauksen sujuvuuteen. Publications of the University of Eastern Finland. Dissertations in Education, Humanities, and Theology 102. Joensuu: Itä-Suomen yliopisto. [verkkoaineisto]. [viitattu 23.12.2017]. Saatavissa: http://urn.fi/URN:ISBN:978-952-61-2434-6.

Ruokonen, Minna. 2016. Realistic but not pessimistic: Finnish translation students' perceptions of translator status. The Journal of Specialised Translation 25, 188-212. [verkkoaineisto]. [viitattu 18.12.2017]. Saatavissa: http://www.jostrans.org/issue25/ art_ruokonen.pdf.

Saldanha, Gabriela \& O'Brien, Sharon. 2013. Research Methodologies in Translation Studies. London: Routledge.

Sandrelli, Annalisa. 2012. Introducing FOOTIE (Football in Europe): Simultaneous interpreting in football press conferences. Julkaisussa: Straniero Sergio, Francesco \& Falbo, Caterina (toim.) Breaking Ground in Corpus-based Interpreting Studies. Frankfurt: Peter Lang, 119-153.

Seleskovitch, Danica \& Lederer, Marianne. 1989. Pédagogie raisonnée de l'interprétation. Bruxelles: Didier.

Shlesinger, Miriam. 1998. Corpus-based interpreting studies as an offshoot of corpus-based 
translation studies. Meta XLIII: 4, 1-8. [verkkoaineisto]. [viitattu 15.12.2017]. Saatavissa: http://citeseerx.ist.psu.edu/viewdoc/download?doi=10.1.1.119.9115\&rep=rep1\&type=pdf.

Shreve, Gregory M. \& Angelone, Erik (toim.). 2010. Translation and Cognition. Amsterdam: John Benjamins.

Szarkowska, Agnieszka, Krejtz, Izabela, Klyszejko, Zuzanna \& Wieczorek, Anna. 2011. Verbatim, standard, or edited? Reading patterns of different captioning styles among deaf, hard of hearing, and hearing viewers. American Annals of the Deaf 156:4, 363-378.

Taivalkoski-Shilov, Kristiina \& Koponen, Maarit. 2017. Contextual factors when reading a translated academic text. Julkaisussa: Alvstad, Cecilia, Greenall, Annjo K., Jansen, Hanne \& Taivalkoski-Shilov, Kristiina (toim.) Textual and Contextual Voices of Translation. Amsterdam: John Benjamins, 81-99.

Tiittula, Liisa. 2016. Vastaanottajien näkemyksiä ohjelmatekstityksen toimivuudesta. Julkaisussa: Hartama-Heinonen, Ritva, Kivilehto, Marja \& Ruokonen, Minna (toim.) MikaEL Kääntämisen ja tulkkauksen tutkimuksen symposiumin verkkojulkaisu 9, 87-101. [verkkoaineisto]. [viitattu 18.12.2017]. Saatavissa: https://www.sktl.fi/@Bin/1591116/ MikaELg_Tiittula.pdf.

Tiittula, Liisa \& Nuolijärvi, Pirkko. 2013. Puheen illuusio suomenkielisessä kaunokirjallisuudessa. Suomalaisen Kirjallisuuden Seuran Toimituksia 1401. Helsinki: Suomalaisen Kirjallisuuden Seura.

Tiittula, Liisa \& Nuolijärvi, Pirkko. 2016. Changing norms in translated Finnish fiction: A study of non-standard varieties. International Journal of Literary Linguistics 5:3, 1-26.

Tommola, Jorma, Laine, Matti, Sunnari, Marianna \& Rinne, Juha O. 2000. Images of shadowing and interpreting. Interpreting 5:2, 147-168.

Toury, Gideon. 1995. Descriptive Translation Studies - and Beyond. Amsterdam: John Benjamins.

Tuominen, Tiina. 2012. The Art of Accidental Reading and Incidental Listening: An Empirical Study on the Viewing of Subtitled Films. Väitöskirja. Tampere: Tampere University Press. [verkkoaineisto]. [viitattu 23.12.2017]. Saatavissa: http://urn.fi/ URN:ISBN:978-951-44-9008-8.

Vik-Tuovinen, Gun-Viol. 2006. Tolkning på olika nivåer av professionalitet. Acta Wasaensia 153. Väitöskirja. Vaasa: Vaasan yliopisto.

Vuorikoski, Anna-Riitta. 1996. Audience Response to Simultaneous Interpreting. Lisensiaatintyö. Käännöstiede (englanti), Tampereen yliopisto.

Vuorikoski, Anna-Riitta. 2004. A Voice of its Citizens or a Modern Tower of Babel? The Quality of Interpreting as a Function of Political Rhetoric in the European Parliament. Acta Universitatis Tamperensis 985. Tampere: Tampereen yliopisto. [verkkoaineisto]. [viitattu 23.12.2017]. Saatavissa: http://tampub.uta.fi/bitstream/ handle/10024/67348/951-44-5878-8.pdf? sequence=1\&isAllowed =y.

Wadensjö, Cecilia. 1998. Interpreting as Interaction. London: Longman.

Walker, Larry. 2017. Communality and conflict: an examination of 'voice' in the Knopf translation of Mishima Yukio's Spring Snow. Julkaisussa: Taivalkoski-Shilov, Kristiina, Tiittula, Liisa \& Koponen, Maarit (toim.) Communities in Translation and Interpreting. Vita traductiva 9. Montréal: Éditions québécoises de l'œuvre, 159-182. 